\title{
Din Görevlileri Gözünden Diyanet İşleri Başkanlığı'nın Amerika Birleşik Devletleri’ndeki Din Hizmetleri
}

\section{Religious Services in the USA Provided by the Turkish Directorate of Religious Affairs From the Eyes of Religious Officials}

\author{
Mustafa BAKIRCI \\ Dr. Öğr. Üyesi, Giresun Üniversitesi, Fen-Edebiyat Fakültesi, Genel Sosyoloji ve Metodoloji Anabilim Dalı \\ Assistant Professor, Giresun University, Faculty of Art and Sciences, Department of General Sociology \\ and Methodology \\ Giresun, Turkey \\ mubakirci@hotmail.com \\ orcid.org/0000-0003-3645-5480
}

\author{
Makale Bilgisi / Article Information \\ Makale Türü / Article Types \\ : Araştırma Makalesi / Research Article \\ Geliş Tarihi / Received \\ : 11 Nisan / April 2019 \\ Kabul Tarihi / Accepted \\ : 11 Mayıs / May 2019 \\ Yayın Tarihi / Published \\ : 15 Haziran / June 2019 \\ Yayın Sezonu / Pub Date Season : Haziran / June \\ Cilt / Volume: 6 - Sayı / Issue: 1 - Sayfa / Pages: 71-101
}

Atıf / Cite as

Bakırcı, Mustafa. "Din Görevlileri Gözünden Diyanet İşleri Başkanlığı́nın Amerika Birleşik Devletleri'ndeki Din Hizmetleri". Bülent Ecevit Üniversitesi Ilahiyat Fakültesi Dergisi, 6/1 (2019): 71-101.

Doi: 10.33460/beuifd.552357

İntihal / Plagiarism

Bu makale, en az iki hakem tarafından incelendi ve intihal içermediği teyit edildi.

This article has been reviewed by at least two referees and scanned via a plagiarism software.

Yayın Hakkı / Copyright ${ }^{\circ}$

Zonguldak Bülent Ecevit Üniversitesi, İlahiyat Fakültesi tarafından yayınlanmıştır. Tüm hakları saklıdır.

Published by Zonguldak Bulent Ecevit University, Faculty of Theology, Zonguldak, Turkey. All rights reserved.

Öz: Diyanet Işsleri Başkanlığı (DiB) yurt içi hizmetlerinin yanında yurt dışında da birçok ülkede din hizmetlerini sürdürmektedir. Bu ülkelerden biri de Amerika BirleşikDevletleri'dir $(A B D)$. Bu araştırma, din görevlileri gözünden DiB'in $A B D^{\prime}$ deki hizmetlerine yönelik bir değerlendirme yapmayı amaçlamaktadır. Araştırmanın temel sorusu, "ABD'de DiB'e bağlı olarak görev yapan din görevlilerinin, yürütülen din hizmetlerine yönelik görüş, eleştiri ve önerileri nelerdir?" şeklindedir. Araştırmada, katılımlı gözlem, görüşme ve doküman analizi gibi nitel veri toplama teknikleri kullanılmış; Kasım 2014-Ağustos 2015 tarihleri arasında başta Din Hizmetleri Müşaviri olmak üzere Maryland, Delaware, Pennsylvania, New Jersey, New York, Connecticut ve Massachusetts eyaletlerinde görev yapan on iki din görevlisi ve iki tane de eski din görevlisi dâhil edilerek toplamda on beş görüşme gerçekleştirilmiştir. DiB ABD'de, yirmi beş civarında camiyle hizmet yürütmektedir. Bu camilerde Türkiye'den gelen göçmenlerin ibadet ihtiyaçlarının karşılanması yanında sosyokültürel hayatlarına etki edecek birçok program ve faaliyet de icra edilmektedir. Ayrıca camilerin dini ve milli kimliğin pekiştirilmesi ve yeni nesillere aktarılmasında 
önemli biryerinin olduğu görülmektedir. Ancak bunun yanında camilerde verilen eğitimin yetersizliğinden mekân problemine kadar DiB'in yürüttüğü hizmetlere yönelik birçok eleştiri de söz konusudur. Bu araştırmanın, söz konusu eleştirileri ele alması bakımından hem $A B D$ 'deki hem de yurt dışındaki din hizmetlerinin daha verimli hale gelmesine katkı sunabileceğini söyleyebiliriz.

Anahtar kelimeler: Din Sosyolojisi, Amerika Birleşik Devletleri, Diyanet Iş̧leri Başkanlığı, Din Görevlileri, Din Hizmetleri

Abstract: Turkish Directorate of Religious Affairs offers services at abroad in addition to its national services. United States of America (USA) is one of these countries. This paper aims to present a general review of these services from the perspective of religious officials. The main question of the paper is that "what are the perspectives, critics and suggestions of religious officials employed by the Directorate of Religious Affairs to work in the USA?". The study draws on qualitative research methods such as participant observation, interview and document analysis. Between November 2014 and August 2015, 15 unstructured interviews were conducted. 12 of them were religious officers who were serving in Maryland, Delaware, Pennsylvania, New Jersey, New York, Connecticut and Massachusetts; 2 of 15 interviewees were retired religious officers and one of them was Counsellor of Religious Affairs. Directorate of Religious Affairs serves around 25 mosques in USA. These mosques are not only important for providing religious services to Turkish migrants but they are also vital to contribute migrants' socio-cultural life. Mosques also play tremendous role in consolidating the religious and national identities as well as in transferring them to next generations. On the other hand, services of Religious Affairs have been subjected to some criticisms such as quality of religious education given in these mosques and lack of space. This study, therefore, will contribute the improvement of services of Directorate of Religious Affairs in USA by tackling on these criticisms.

Keywords: Sociology of Religion, USA, Directorate of Religious Affairs, Religious officials, Religious services.

\section{GíRiş}

Diyanet İşleri Başkanlığı (DiB), yeni kurulan Türkiye Cumhuriyeti'nde Şeyhülislamlık bünyesindeki bazı işleri deruhte etmek üzere kurulan Şeriyye ve Evkaf Vekâleti'nin dinle ilgili kısmını yürütmek üzere, 3 Mart 1924 tarih ve 429 sayılı Kanun'la, İslam dininin itikat ve ibadet alanıyla ilgili işlerini yürütmek ve dini kurumları idare etmek amacıyla kurulmuş bir kurumdur. ${ }^{1}$ Daha sonra görev alanları ve idari yapısına yönelik birçok değişikliğin yapıldığı DiB'in kurulduğu günden itibaren Türkiye'nin sosyo-politik gündemindeki sıcak yerini her zaman koruduğu; laik Cumhuriyet içerisindeki meşruiyetinden bütçedeki payına, ürettiği hizmetin niteliğinden Sünnilik dışı yapıları temsil problemine kadar onlarca tartışmanın içinde yer aldığı söylenebilir. ${ }^{2}$

1 İrfan Yücel, "Diyanet İşleri Başkanlığı", Türkiye Diyanet Vakfı İslâm Ansiklopedisi (Ankara: TDV Yayınları, 1994), 9: 455.

2 İsmail Kara, Cumhuriyet Türkiye'sinde Bir Mesele Olarak Islam (İstanbul: Dergâh Yayınları, 2008), 53. 
DiB merkez, taşra ve yurt dışı teşkilatlarından oluşmaktadır. Başta başkan ve başkan yardımcılarının yer aldığı merkez teşkilatında kurullar, daire başkanlıkları, müdürlükler ve çeşitli birimler; taşra teşkilatlarında il ve ilçe müftülükleriyle eğitim merkezleri yer almaktadır. Yurt dışı teşkilatı ise, Türk göçmenlerin bulunduğu Batı ülkeleriyle Orta Asya Türk Cumhuriyetlerindeki büyükelçilik ve başkonsolosluklar nezdinde müşavirlik ve ataşeliklerinden oluşmaktadır. ${ }^{3}$ Yurt dışı hizmetlerine 1971 yılında, Türk göçmenlerin yaşadıkları şehirlerde kurdukları ibadet yerlerindeki hizmetlerin yürütülmesiyle ilgili talepleri üzerine başlamış olan DiB, bugün Avrupa ülkeleri başta olmak üzere birçok ülkede yaşayan Türk göçmenlerin din görevlisi ihtiyacını karşılamaktadır. Yukarıda bahsedilen Kanun'da Dỉ'in yurt dışına din görevlisi göndermek dışında, İslam dini ile ilgili gelişmeleri, dinî, ilmî faaliyetleri, neşriyatı ve dinî propaganda mahiyetindeki çalışmaları takip etmek, bunları değerlendirmek ve sonucu Başkanlığa sunmak; yurt dışında yaşayan vatandaş, soydaş ve İslam dinine mensup topluluklara yönelik değişik dil ve lehçelerde yayınlar hazırlamak, hazırlatmak ve gerektiğinde bunları ücretsiz dağıtmak; yurt dışında görevlendirilecek personelin eğitim ihtiyaçlarını belirlemek ve eğitim planlarını hazırlamak, personelin seçimi ve bu görevlere hazırlanmaları ile ilgili işleri yürütmek; yurt dışında İslam dini ve diğer dinlerle ilgili olarak yapılan çalışmaları takip etmek, incelemek ve değerlendirmek; yurt dışı din hizmetlerinin etkin ve verimli bir şekilde yürütülmesine katkı sağlayacak altyapıya ve dinî tesislere ilişkin iş ve işlemleri yürütmek gibi birçok konuda görev ve sorumluluklarının olduğu görülmektedir. ${ }^{4}$

Çok sayıda Türk göçmenin yasadığı ABD, DiB'in yurt dışındaki görev ve sorumluluklarının kapsamına giren ve din görevlisi gönderdiği ülkelerden biridir. Ancak bugüne kadar DiB'in ABD'deki hizmetlerine yönelik çok az sayıda çalışma yapılabilmiştir. Bu çalışmalara örnek olarak verilebilecek çalışmalardan biri, 1998-2003 yılları arasında Dỉ bünyesinde ABD'de görev yapan ve daha sonraki yıllarda da ABD ziyaretlerinde DiB hizmetlerine yönelik gözlemlerde bulunan Yavuzer'e aittir. ${ }^{5}$ Yavuzer'in makalesinde, başlangıcından 2010 yılına kadar DiB'in ABD'deki kurumsallaşma sürecine dair bilgiler yer almaktadır. Güngör'e ait iki çalışmada da ABD'de yaşayan Türk göçmenlerin dini ve kültürel varlıklarını sürdürmek için kurdukları camiler ve bu kurumların sorunlarına dair çeşitli problemler sosyolojik açıdan ele alınmış; Türk göçmenlerin son yıllarda, 11 Eylül hadisesinin Müslümanlar üzerindeki kötü etkilerine rağmen, farklı alanlarda kurumsallaşmalarını hızlandırdıkları ve gelecek nesillere kültür ve kimliklerini aktarmak için cami temelli örgütlenmelerini sürdürdükleri ifade

3 Yücel, “Diyanet İşleri Başkanlığı”, 457-458.

4 Mevzuat Bilgi Sistemi (MBS). Diyanet İşleri Başkanlığı Kuruluş Ve Görevleri Hakkında Kanun, 1965. Erişim: 28.07.2018. http://www.mevzuat.gov.tr/MevzuatMetin/1.5.633.pdf

5 Hasan Yavuzer, "Amerika'daki Türkler ve Kendilerine Götürülen Din Hizmetleri”, Türk Dünyası Araştırmaları 189 (2010): 159-183. 
edilmiştir. ${ }^{6}$ Güngör tarafından yapılan diğer iki çalışmada da ABD'deki Türk göçmen çocuklarının, camilerin ve dini grupların etkilerininim de göz önünde bulundurulduğu, dini sosyalleşmeleri konusu farklı şekillerde ele alınmıştır.? Washington Din Hizmetler Müşavirliğince başlatılan ve 2013 ve 2014 yıllarında ABD'de Tekelioğlu tarafından gerçekleştirilen araştırma projesinde ise daha ziyade ABD'deki genel dini yapıya, İslam'ın ABD'deki tarihsel varlığına ve özellikle de 11 Eylül sonrası duruma yönelik genel bir değerlendirme yapılmakta ancak DiB'in hizmetlerine yönelik bilgi ve değerlendirmeler yer almamaktadır. ${ }^{8}$

ABD'deki DiB hizmetlerine ve $A B D$ genelinde Türk göçmenlerin dini ve kültürel hayatına yönelik faaliyet gösteren Türkiye kaynaklı dini gruplara yönelik bilgi edinmemize ve değerlendirmeler yapmamıza imkân verecek yeterli düzeyde çalışmaların olmadığını belirtmek gerekir. Bu bakımdan, ABD'de görev yapan din görevlileri ile yapılan görüşmelere dayalı nitel bir çalışma olarak DiB'in ABD'deki hizmetleriyle ilgili genel bir değerlendirme yapmayı amaçlayan bu çalışmanın literatüre önemli bir katkı sağlayacağı söylenebilir.

ABD yaklaşık on milyon kilometrekare toprağa sahip, elli eyalet ve bir federal bölgeden oluşan ve araştırmanın yapıldığı 2015 yılı itibariyle nüfusu üç yüz yirmi milyon civarında olan bir ülkedir. ${ }^{9}$ Bu nüfusun büyük bir kısmını Hristiyanlar ve özellikle de Protestanlık mezhebine bağlı olanlar oluşturmaktadır. Yahudi nüfusu ise beş-altı milyon civarındadır. Müslüman nüfusu hakkında ise net bir rakam bulunmamakta; iki milyon ile üç milyon arasında rakamlar telaffuz edilmektedir. ${ }^{10}$ ABD'deki Müslüman varlığına dair yapılan bazı çalışmalarda ise bu sayı dört ile yedi milyon arasında tahmin edilmektedir. ${ }^{11}$ Pew Araştırma Merkezi'nin ortaya koyduğu rakam ise üç milyon üç yüz bindir ki bu rakam genel nüfusa göre ABD'de yaşayan Müslüman nüfusun yüzde bire bile ulaşmadığını göstermektedir. ${ }^{12}$

ABD'deki Türk varlığının oldukça eskilere dayandığı, ancak Osmanlı coğrafyasından Amerika'ya göç edenlerle ilgili yapılan tanımlamalarda "Türk" ifadesinin daha ziyade Müslüman olanları kapsayan dini bir sıfat olarak kullanıldığı; 1860'lardan itibaren Osmanlı topraklarından Amerika'ya göç eden on binlerce insan için de "câliye" tabirinin kullanıldığı bilinmektedir. ${ }^{13}$ Osmanlı

6 Özcan Güngör, "The Process of Religious Institutionalization (Concept of Mosque) of Turkish in the US", International Journal of Business and Social Science 2/8 (2011): 211-222; Özcan Güngör, "Amerika'da Türkler ve Türklerin Dini Kurumsallaşmaları Açısından Camiler", Ekev Akademi Dergisi 15/47 (2011): 85-101.

7 Özcan Güngör, "1.5 ve 2. Nesil Türk Gençlerinin Ailede Dini Sosyalleşmeleri: New Jersey, USA Örneği", Ankara Üniversitesi Illahiyat Fakültesi Dergisi 53/2 (2012): 85-119; Özcan Güngör, "Akran Gruplarının Amerikalı Türk Gençlerinin Dini Sosyalleşmelerine Etkileri (12-15 Yaş)", Değerler Eğitimi Dergisi 12/30 (2015): 213-249.

8 Ahmet Selim Tekelioğlu, Yerleşme ve Yerelleşme Arasında Amerika'da İslam ve Müslümanlar: Tarihi Perspektif ve Güncel Dinamikler (Vaşington: Diyanet Center of America, 2017).

9 Worldometers,. "Countries in the World by Population". 2017.

10 John J. Macionis, Sociology (New Jersey: Upper Saddle River, Pearson Education, 2012), 322.

11 Jane I. Smith, "Islam in America", Muslims in the West after 9/11: Religion, Politics and Law, ed. Jocelyne Cesari, (Routledge, 2009), 38-52.

12 Michael Lipka, "Muslims and Islam: Key Findings in the US and around the World". Pew Research Center 9 (2017).

13 Kemal Karpat, "Câliye”, Türkiye Diyanet Vakfı İlâm Ansiklopedisi (Ankara:TDV Yayınları, 1993), 7:34-38. 
zamanında başlayan göç hareketliliğinin 1920'lere kadar sürdüğü, bu tarihten 1950'lere kadar durduğu; 1950-70 arasında tekrar bir göç hareketliliğinin yaşandığı ve özellikle Johnson hükümetinin yaptığı 1965 tarihli göçmenlik yasasının bu hareketi hızlandırdığı söylenebilir. 1980'den sonra tekrar başlayan göç hareketliliğinin ise 2000 'lere kadar hızlı bir şekilde devam ettiği ve sonrasında ise azaldığı görülmektedir. ${ }^{14}$ Bugün elimizde ABD'deki Türk nüfusuna dair resmi bir rakam bulunmamakla birlikte, çeşitli kaynaklarda yer alan bilgiler dikkate alındığında $A B D$ 'de yaşayan Türk nüfusun üç yüz ile beş yüz bin arasında olduğu tahmin edilmektedir. ${ }^{15} 2010$ yılı verilerine göre coğrafi olarak Türklerin \%36'sı Kuzeydoğu eyaletlerinde, \%31'i Güney eyaletlerinde, \%20'si Batı eyaletlerinde ve $\% 12$ 'si Orta-Batı eyaletlerinde yaşamaktadır. ${ }^{16}$

Türkiye'den 1960'lı yılların başından itibaren Avrupa'ya "misafir işçci" olarak giden Türk vatandaşlarının ilk teşebbüslerinden biri en azından Cuma ve bayram namazlarını kılabilecekleri bir yer bulmak olmuştur. Bu yerler genellikle şehirlerin sanayi bölgelerinde veya arka sokaklarında baraka, eski atölye, bodrum katı, depo tarzı derme-çatma yelerlerden dönüştürülmüş ve "arka avlu camileri" olarak nitelendirilmiş yerlerdir. ${ }^{17}$ Avrupa'ya kitlesel göçün yaşandığı ilk zamanlarda imkânsızlıklar içinde inşa edilen bu mescitler, daha sonra hem ihtiyaç ve beklentilerin artması hem de Türkiye kökenli dini grup ve cemaatlerin devreye girmesiyle yerlerini daha büyük ve güzel mescit ve camilere bırakmıştır. ${ }^{18}$ Bugün itibariyle bu camilerin sadece dar anlamda dini hizmetlerle sınırlı kalmadığı, göçmenlerin sosyokültürel ihtiyaçlarına yönelik her türlü faaliyetin yer aldığı ve aynı zamanda bir buluşma ve sosyalleşme alanı olduğu görülmektedir. ${ }^{19}$ Aynı şekilde ABD'de de, 1970'li yılların başından itibaren Türk göçmenlerin iş yerlerinin veya evlerinin büyük odalarını ve zemin katlarını (basement) mescit olarak kullandıkları; cuma ve bayram namazları yanında çocuklarına dini bilgileri de bu şartlar altında vermeye çalıştıkları; zor şartlar altında dini ibadetlerini gerçekleştirmeye çalışan bu göçmenlerin çoğu zaman cuma namazlarını

14 Kemal Karpat, "The Turks Finally Establish a Community in the United States", Turkish Migration to the United States: From Ottoman Times to the Present, ed. A. Deniz Balgamis - Kemal. H. Karpat (University of Wisconsin Press, 2008), 173-193; İlhan Kaya, “Amerikalı Türkler", Coğrafi Bilimler Dergisi 4/2 (2006): 1-13; İlhan Kaya, Müs/üman Amerikalılar: Göç, Kimlik ve Entegrasyon (Ankara: Dipnot Yayınları, 2007), 69, 109.

15 Kaya, Müslüman Amerikalılar: Göç, Kimlik ve Entegrasyon, 49.

16 Tekelioğlu, Yerleşme ve Yerelleşme Arasında Amerika'da İslam ve Müslümanlar: Tarihi Perspektif ve Güncel Dinamikler, 57.

17 Nermin Abadan Unat, Bitmeyen Göç: Konuk Işçilikten Ulus-Ötesi Yurttaşlı̆̆a (İstanbul: İstanbul Bilgi Üniversitesi Yayınları, 2006), 266; İrfan Başkurt, "Almanya'da Yaşayan Türk Göçmenlerin Kimlik Problemi", Hasan Ali Yücel Eğitim Fakültesi Dergisi 12/2 (2009): 82.

18 Yakup Çoştu - Mehmet Akif Ceyhan, "DiTiB'in Din Eğitimi Faaliyetleri Üzerine Bir Değerlendirme”, Hitit Üniversitesi Sosyal Bilimler Enstitüsü Dergisi 8/1 (2015): 43; Yakup Çoştu, Ingiltere'de Türkler (Yapı ve Organizasyonlar) (Ankara: Araştırma Yayınları, 2018), 110-111; Mustafa Tavukçuoğlu, Belçika'da Türk Ailesi ve Din Eğitimi, (Konya: Mehir Vakfı, 2000), 53-54.

19 Yakup Çoştu - Süleyman Turan, "Ingiltere'deki Türk Camileri ve Entegrasyon Sürecine Sosyo-Kültürel Katkıları”, Dinbilimleri Akademik Araştırma Dergisi 9/4 (2009): 36; İsmail Güllü, "Yeni Türk Sosyolojisi Bağlamında Almanya'daki Göçmen Türk Çocuklarının Dini Toplumsallaşması", Sosyoloji Divanı 3/6 (2015): 83-102; Tavukçuoğlu, Belçika'da Türk Ailesi ve Din Eğitimi, 28. 
kılamadıkları gibi Ramazan ve bayram günlerini dahi bilemedikleri; bayram namazı için gittikleri uzak camilerde bayramın bir önceki veya bir sonraki gün olduğunu öğrenerek geri döndükleri bilinmektedir. ${ }^{20}$

ABD'deki Türk göçmenlerin uzun yıllar başka Müslüman toplumların açmış oldukları camilerde ibadet ettikleri ve Türkiye devletinin göçmenlerin ibadet yerlerine ve görevlilerine dair gerekli adımları atmadığı görülmektedir. ${ }^{21}$ DiB'in ABD'deki faaliyetleri 1988 yılında Din Hizmetleri Müşaviri atamasıyla başlamış, bir yıl sonra New York eyaletine bir din görevlisi gönderilmiş ve sonrasında ise uzun yıllar din görevlisi gönderilmemiştir. ${ }^{22}$ DiB'in ABD'de kurumsallaşma anlamında ilk adımı ise 1993 yılında Din Hizmetleri Müşavirinin başkanlığında Maryland eyaletinde Turkish American Islamic Foundation (TAIF) isminde bir vakfın kurulması olmuştur. ABD'deki Türk ve Müslüman gruplara yönelik dini ve sosyokültürel alanlarda hizmet vermeyi amaçlayan bu kuruluş, bir taraftan ABD'deki Türk göçmenlerin din görevlisi ihtiyaçnı karşılamaya çalışırken, diğer taraftan da bugün Diyanet Center of America (Amerika Diyanet Merkezi) olarak isimlendirilen külliyenin altmış dönümlük arazisini satın alarak önemli bir hizmeti gerçekleştirmiştir. DiB'in din görevlisi gönderdiği cami dernekleri ise, 2003 yılında feshedilen TAIF'in yerine kurulan Turkish American Community Center (TACC) isminde bir çatı kuruma bağlı olarak faaliyet yürütmektedir. ${ }^{23}$ Din Hizmetleri Müşavirinden alınan bilgiye göre 2015 yılı itibariyle ABD'de DiB'in bünyesinde yirmi beş civarında camide din hizmetleri yürütülmektedir

Uzun yıllardan bu yana ABD'deki camiler üzerine uzmanlaşan Dr. Ihsan Bagby'nin 1994, 2000 ve 2011 yılında yayınladığı raporlar, kendisinin de ifade ettiği şekliyle, ABD'deki bütün camilere yönelik tam bir bilgi vermemekle birlikte elimizdeki en kapsamlı çalışma olması nedeniyle önemlidir. Bu raporlara göre camilerin kuruluş yıllarına göre en yüksek oran 1990-99 arasında görülmüş (\%28), bu oran 2000-2009 yılları arasındaki 11 Eylül sonrası dönemde \%24 olarak tespit edilmiştir. ABD'deki cami sayısı 1994 yılında 962 olarak kaydedilmiş, bu rakam 2000 yılında \%26 oranında yükselerek 1209'a çıkmış, 2011 yılında \%74'lük dikkat çekici bir artışla 2106'ya ulaşmıştır. 2011 yılı verilerine göre sırasıyla New York (257 cami), California (246 cami) ve Texas (166) en fazla camiye sahip ilk üç eyalet olarak sıralanmıştır. ${ }^{24}$

20 Yavuzer, "Amerika'daki Türkler ve Kendilerine Götürülen Din Hizmetleri”, 163-164.

21 IIhan Kaya, Shifting Turkish American Identity Formationsin the United States (Doctoral dissertation, Florida State University, 2003), 132-133.

22 Yavuzer, "Amerika'daki Türkler ve Kendilerine Götürülen Din Hizmetleri”, 164.

23 Hasan Yavuzer, “Amerika'daki Türkler ve Kurmuş Oldukları Türk Dernekleri”, Zeitschrift für die Welt der Türken/Journal of World of Turks 1/1 (2009): 185-186.

24 Ihsan Bagby, "The American Mosque: Report Number 1 from the US Mosque Study 2011", Islamic Society of North America 1/2 (2012); Tekelioğlu, Yerleşme ve Yerelleşme Arasında Amerika'da İslam ve Müslümanlar: Tarihi Perspektif ve Güncel Dinamikler. 


\section{KONU VE ÖNEM}

DiB, yurt dışında birçok ülkede olduğu gibi, ABD'de de Türk göçmenlere yönelik din hizmetleri vermektedir. Ancak bu hizmetler doksanların başında başlayabilmiş ve yakın zamana kadar da ciddi bir gelişme gösterememiştir. 2013 yılında Maryland eyaletinde bulunan altmış dönümlük araziye Osmanlı mimarisine uygun bir cami ve külliyenin yapımına başlanması, çeşitli eyaletlerdeki cami sayısını arttırma çabaları ve mevcut camilerin durumlarını iyileştirmek gibi adımlar son dönemlerde DiB'in ABD'deki hizmetlerindeki olumlu gelişmeler olarak değerlendirilebilir.

Türk göçmenlerin Avrupa'da açtıkları camiler gibi, ABD'deki camiler de çok fonksiyonlu, çeşitli dini ve sosyokültürel etkinliklerin yapıldığı oldukça faal mekânlar/kurumlar olup, dini faaliyetlerin yanında birçok milli ve kültürel faaliyetlere de ev sahipliği yapmaktadır. ${ }^{25} \mathrm{Bu}$ durum camileri, tıpkı başka Müslüman milletlerin/toplumların hayatında olduğu gibi $A B D^{\prime}$ deki Türk göçmenlerin hayatında da önemli bir yere yerleştirmektedir.

ABD'de dini, milli ve kültürel alanda birçok önemli faaliyetin icra edildiği camilerle ilgili bazı konuların da müzakere edildiği bilinmektedir. Tekelioğlu'nun raporunda da dikkat çektiği gibi $A B D^{\prime}$ deki camilerle ilgili olarak dile getirilen problemlerin başında camilerde ortaya koyulan hizmetlerin yetersizliği gelmektedir. En başta fiziki alanların yeterli olmaması, kadın ve çocukların camilerdeki yeri, camilerde siyasetin yer alıp almayacağı, gençlere dönük programların nasıl geliştirileceği, din görevlilerinin eğitimi ve maaşları, cenaze hizmetlerinin sağlanmasındaki lojistik sorunlar, camilerde yürütülen okul/eğitim faaliyetlerinin içerik ve kalitesi, cami yönetimi ve derneklerindeki problemler, birçok farklı nedenle camilerden uzaklaşan ve kendilerinin camilerde yer bulamadığını belirten insanların problemleri, $A B D$ devletinin güvenlikçi yaklaşımları ve İslamofobik saldırılar gibi daha birçok problemi sıralamak mümkündür. ${ }^{26}$

DiB'in birçok ülkede yürüttüğü din hizmetleri gibi $A B D^{\prime}$ de yürüttüğü din hizmetleri de önem arz etmektedir. Hatta diğer ülkelerden farklı olarak, yukarıda da bahsedildiği gibi, özellikle 11 Eylül sonrasında "islamofobinin" bir endüstriye dönüştürüldüğü ${ }^{27}$ göz önüne alındığında, Türk göçmenlerin ve gelecek nesillerin dini ve kültürel hayatının şekillenmesi başta olmak üzere $A B D^{\prime}$ de toplumun İslam dini hakkında sağlıklı bilgi edinmesi konusunda da ABD'deki DiB hizmetlerinin hayati öneme sahip olduğu ve bu faaliyetlerin daha nitelikli ve etkili bir şekilde

25 Karpat, "The Turks Finally Establish a Community in the United States", 173-193; Kaya, Shifting Turkish American Identity Formationsin the United States.

26 Tekelioğlu, Yerleşme ve Yerelleşme Arasında Amerika'da Islam ve Müslümanlar: Tarihi Perspektifve Güncel Dinamikler, 53-54.

27 Nathan Lean, İslamofobi Endüstrisi, trc. İbrahim Yılmaz (Ankara: Diyanet İşleri Başkanlığı Yayınları, 2015). 
yapılabilmesinin ise bu faaliyetlere yönelik akademik çalışmaların artmasıyla doğrudan ilişkili olduğu söylenebilir. Bu anlamda bu çalışma, DiB'in ABD'de daha iyi hizmet sunabilmesine katkı sağlayarak, Türk göçmenlerin dini ve kültürel hayatının iyileştirilmesini hedeflemektedir.

Araştırmanın konusu, din görevlilerinin gözünden DiB'in ABD'deki hizmetleridir. Araştırmanın temel sorusu, "ABD'de DiB'e bağlı olarak görev yapan din görevlilerinin, DiB'in $A B D$ 'de yürütmüş olduğu din hizmetlerine yönelik görüş, eleştiri ve önerileri nelerdir?" şeklindedir. ${ }^{28}$

\section{YÖNTEM}

Araştırma nitel bir araştırma olup; görüşme ve doküman analizi tekniklerinden yararlanılmıştır.Bunagöre,ABD’nin Maryland, Delaware, Pennsylvania, New Jersey, New York, Connecticut ve Massachusetts eyaletlerinde DiB'e bağlı olarak hizmet veren camilerde görev yapan on iki din görevlisiyle görüşme gerçekleştirilmiştir. Ayrıca daha önce New Jersey ve Pennsylvania eyaletlerinde DỉB'e bağlı camilerde resmi din görevlisi olarak görev yaptıktan sonra görevlerinden ayrılarak ABD'ye yerleşmiş iki din görevlisi de görüşmelere dâhil edilmiş ve bu şekilde müşavirle birlikte toplam görüşmeci sayısı on beşi bulmuştur. Görüşme ve gözlemler, Kasım 2014-Ağustos 2015 tarihleri arasında, Din Hizmetleri Müşavirinin bilgisi dâhilinde gerçekleşmiştir. Görüşmecilere, çalışmanın amacıyla ilgili ön bilgi verildikten sonra $A B D$ 'deki DiB hizmetlerini nasıl değerlendirdiklerine dair genel bir soru yöneltilmiş; cami hizmetlerinde karşılaştıkları problemlerden, çocukların eğitimine, müşavirlik ve dernekle olan ilişkilerden dil problemine kadar birçok meseleyle ilgili görüş, eleştiri ve değerlendirmeleri not edilmiştir. Görüşme formu içerisinde yer almayan, ancak görüşmeciler tarafından dile getirilen Türk okulları açılması, Uluslararası İlahiyat Projesi, Dỉ'in bir "geleneğinin olmaması" ve din görevlilerinin gündelik hayatlarına dair problemler gibi konulara da bulgular kısmında yer verilmiştir.

Görüşmecilerden, görüşme yapılan kişiler olarak isimlerinin yazılmasına yönelik izin alınmış ancak görüş, öneri ve eleştirilerinde isim belirtilmeyeceği ifade edilmiştir. Bu bakımdan görüşmecilere ait ifadeler, aşağıdaki sıralamayla ilgili olmaksızın, "G1, G2..." şeklinde yer almıştır.

Görüşmecilerle ilgili bilgiler şu şekildedir: Washington Büyükelçiliği Din Hizmetleri Müşaviri Dr. Yaşar Çolak; Marlyland/Lanham, TACC bünyesinde yer alan camide görevli Ali Tos ve Belgizar Özbek; Delawere/Delaware Diyanet Camii din görevlisi İbrahim Yavaş; New Jersey/Monroeville Murat Camii din görevlisi Ali Muslu; New Jersey/Burlington Selimiye Camii din görevlileri Ömer Okuyucu ve Seher Okuyucu; Pennsylvania/Levittown Yunus Emre Camii (TAMCA) din görevlisi

28 Bu çalışma, TÜBITAK'ın doktora sonrası yurt dışı araştırma bursuyla gittiğim ABD'de, Giresunlu göçmenlerin dini ve kültürel hayatına dair yaptığım çalışmayla eş zamanlı olarak yapılmış bir çalışmadır. 
Bayram Erkek; New Jersey/Peterson Ulu Camii din görevlisi Mustafa Bahacan; New York/Brooklyn Eyüp Sultan Camii din görevlisi Illyaz Gönen; New York/Long Island Mevlana Camii din görevlisi Raşit Koç; Connecticut/New Haven Diyanet Camii din görevlisi Muhammet Naci Efe; Massachusetts/Springfield İmam Buhari Camii din görevlisi Basri Canpolat. Ayrıca daha önce DiB bünyesinde ABD'de din görevlisi olarak çalışmış ve görevinden ayrıldıktan sonra ABD'de yaşamaya devam eden Fatih Dursun ve İbrahim Ünal da görüşmelere dâhil edilmiştir. Bu kişilerden Fatih Dursun, başta ABD genelinde sayıları yirmi bine ulaşan Ahıska Türkleri ${ }^{29}$ olmak üzere DiB'in $A B D^{\prime}$ deki birçok hizmetinde müşavirlikle irtibatlı olarak fahri bir şekilde çalışmalarına devam etmektedir. İbrahim Ünal ise kendi ticari işleri yanında camilerde ve evlerde icra edilen dini merasimlere zaman zaman davet edilmekte ve katılmaktadır.

\section{BULGULAR}

Bulgular kısmında ilk olarak Washington Din Hizmetleri Müşaviri Dr. Yaşar Çolak'ın ABD'deki din hizmetlerine yönelik değerlendirmelerine yer verilmiştir. Dỉ'in yurt dışı hizmetlerinde Din Hizmetleri Müşavirliğinin ve müşavirin hayati bir öneme sahip olduğunu belirtmek gerekir. Bu bakımdan hem müşavirin ABD'deki din hizmetlerine yönelik değerlendirmeleri hem de din görevlilerinin müşavirliğin hizmet ve yaklaşımlarına karşı değerlendirilmeleri tespit edilmeye çalışılmıştır.

DiB'in yurt dışı hizmetlerinde en önemli konu başlıklarından birinin camilerde çocuklara verilen din eğitimi olduğunu söyleyebiliriz. Türk göçmenlerin son derece önem verdikleri anlaşılan bu konu, görüşmecilerin dile getirdikleri "okul" konusuyla birlikte, "Camilerde Çocuklara Yönelik Dini Eğitim Faaliyetleri ve Okul Talebi" başlığı altında değerlendirilmiştir. DiB'in yurt dışı hizmetlerinde gittikçe önemi artan konulardan biri de kadın din görevlisi istihdamıdır. İkisinin kadın din görevlisi olduğu görüşmecilerin konuyla ilgili değerlendirmeleri, "Kadın Din Görevlileri" başlığı altında ele alınmıştır. Din görevlisi istihdamıyla ilgili olan bir diğer konu ise, göçmen gençlerden lise mezunu olanlara Türkiye'de ilahiyat eğitimi verilerek yerleşik oldukları ülkelerde din hizmeti verme imkânı sunulmasıdır. Bu konu, "Uluslararası İlahiyat Projesi” başlığı altında ele alınmıştır. Yurt dışı hizmetlerinde bir başka problem ise hiç şüphesiz "yabancı dil" konusudur. Görüşmecilerin konuya ilgin görüşleri, "Din Görevlilerinin Dil Problemi" başlığı altında incelenmiştir. Son olarak din görevlilerinin özlük hakları ve gündelik hayatlarına dair yaşadıkları problemler, "Din Görevlilerinin Özlük Haklarına ve Gündelik Hayatlarına Dair Problemler" başlığı altında ele alınmıştır.

29 Halil Kurt - Mehmet Ali Açıkgöz, "ABD'de Yaşayan Ahıska Türkleri”, MUTAD 4/1 (2017): 107-127. 


\subsection{Washington Din Hizmetleri Müşavirinin Değerlendirmeleri ve Müşavirlikle İlişkiler}

Alan çalışmasının yapıldığı Kasım 2014-Ağustos 2015 tarihleri arasında, ilk bir ayda daha yoğun olmak üzere, çeşitli programlar vesilesiyle Türkiye'nin Washington Büyükelçiliği Din Hizmetleri Müşaviri ile birçok kez görüşme imkânı olmuştur. Alan çalışmasının yapıldığı dönemde, oldukça yoğun bir programla çalışmak durumda olan müşavirin en fazla zamanını alan işlerden birinin Maryland eyaletine yapılmakta olan cami ve külliye (Diyanet Center of America) olduğu, bunun dışında ABD'nin çeşitli eyaletlerinde bulunan camilerin ve çeşitli kurum ve kuruluşların program ve etkinliklerine ve bunların yanında özellikle Türk göçmenlerin cenazelerine katılmaya da özen gösterdiği söylenebilir.

Müşavirle yapılan görüşmelerde Türk toplumunun inanç ve kültürünü koruması ve bunu gelecek nesillere aktarabilmesi meselesi sıkça gündeme gelmiştir. Aynı zamanda sosyal bilim alanında doktor olan Din Hizmetleri Müşaviri, önceliğin yeni nesillerin dini ve kültürel değerlere bağlı olarak yetiştirilmesine verilmesi gerektiğini, Türk göçmenlerden çok önceleri Amerika'ya gelmiş göçmen çocuklarının bir kısmının bugün kendilerini, atalarının geldiği ülkeyi/ milleti kastederek, "... kökenli Amerikalı” şeklinde tanımladıklarını, bazılarının ise kökenlerine dair hiçbir bilgi ve ilgisinin olmadığını ifade etmiş; gerekli adımların atılmaması durumda ABD'deki Türk göçmenlerin çocukları için de aynı durumun geçerli olacağına dikkat çekmiştir.

“Buraya çok uzun yıllardır Türkiye'den göçmen geliyor. Çok geriye gitmeye gerek yok, 30-40 yıl önceden gelen Türk göçmenler içerisinde bile bugün Türk inanç ve kültürüyle irtibatı kalmamış insanlar var. Bu insanlara yeteri kadar sahip çıkılmamış. Amerikan yaşam tarzı bu insanları içinde eritmiş. Anglosakson kültürü dediğimiz bu kültür, insanları farkında olmadan, özgürlük ortamı içinde eritiyor. Müşavirlik olarak biz mümkün olduğu kadar Türk göçmenlerin hasta ziyareti, cenaze, mevlit merasimi ve benzeri cemiyetlerine katılmaya; kederli ve sevinçli zamanlarında yanlarında olmaya çalışıyoruz. En azından bir din görevlisi arkadaşımızı yönlendiriyoruz. Son günlerini yaşayan bazı hastalarımızı ziyaret ettiğimizde, çocuklarından, torunlarından ve akrabalarından başında Kur'an okuyacak veya dua edecek kimsenin olmadığını görmek bizi üzüyor. Türk göçmenler içerisinde cenazesini yakma kararı alan aile fertleriyle bile karşılaştık maalesef. Bu insanlara bunun bizim inanç ve kültürümüze aykırı olduğunu, Müslüman bir cenazenin sadece ailesine değil, bütün Müslüman bir topluma ait olduğunu ve bunu yapmamaları gerektiğini anlatmaya çalıştık. Gerçekten nazik insanlar, bizleri dinlediler, ama maalesef kararlarından vazgeçiremedik. Bunu, sahip çıkılmaması durumunda Türk göçmenlerin inanç ve kültür hayatının nereye gideceğine dair çarpıcı bir örnek olsun diye veriyorum" (Müşavir). 
ABD'de özellikle altmışlı yılların başından beri, göçmenlerin ABD'de hakim Anglosakson kültürü, her hangi bir "baskı" ve "zorlamaya" maruz kalmadan benimsemeleri ve içselleştirmeleri anlamında kullanılan "erime potası" ve bağlantılı orak kullanılan "uyum", "entegrasyon", "asimilasyon", "kültürel çoğulculuk" gibi kavramlar etrafında birçok tartışmanın yapılmaya başlandığı bilinmektedir. ${ }^{30}$ Günümüze kadar süregelen bu tartışmalarda göçmenlerin Amerikan popüler kültüründen nasıl etkilendikleri ve deneyimledikleri, bu kültürü yeni nesillere nasıl aktardıkları ve nesillerdeki kültürel değişmenin nasıl olduğu, kendilerini ne şekilde "Amerikalı" olarak gördükleri, hangi yasaların ve teknolojik gelişmelerin Amerikan popüler kültürüne erişimlerinde büyük rol oynadığı, Amerikan popüler kültüründe "göçmen" olgusunun nasıl yer aldığı ve kullanıldığı gibi onlarca meselenin göçmenlik çalışmaları içeresinde yer aldığı görülmektedir. ${ }^{31}$ Pek çok Amerikalı, Müslümanların, siyahilerin ve diğer göçmenlerin, kendilerini tatmin edecek düzeyde Amerikan kültürünü benimsemediklerini, "erime potası" ideolojisinin işe yaramadığını düşünmektedir. ${ }^{32}$ Read, "erime potası" etrafında yapılan tartışmanın büyük oranda göçmenlerin Amerikan toplumuna entegrasyonlarına yönelik yapılan farklı değerlendirme kriterlerinden kaynaklandığını belirtmektedir. Bazı akademisyenler ekonomik başarıya odaklanırken, bir kısmı evlenme modellerine, bir kısmı da hala politik mobilizasyonun önemini vurgulamaktadır. Bazıları ise göçmenlerin eğitim ve dini alanların da dâhil olduğu sivil toplum etkinliklerine katılımını önemsenmekte ve bu tür katılımların Amerikan popüler kültürüne katılımdan daha önemli olduğunu vurgulamaktadır. ${ }^{33}$

Tartışmayı/konuyu $\mathrm{ABD}$ yaşayan Türk göçmenler üzerinden ele almak gerekirse, Amerikan kültürünün Türk göçmenler ve özellikle de ABD doğumlu olanlarda oldukça etkili olduğu söylenebilir. Güngör'ün çalışmasında ABD'deki birinci nesil göçmenlerin aksine $A B D^{\prime}$ de doğmuş, büyümüş ve eğitim almış Türk göçmen çocuklarının kendilerini daha çok "Amerikalı" olarak gördükleri tespit edilmiştir. ${ }^{34}$ Nitekim müşavir ve görüşmeciler, çocukların okul ortamında ve sokaklarda etkin bir şekilde kutlanan ve çoğu Hristiyanlıkla ilgili olan Noel, Şükran Günü, Paskalya ve Cadılar Bayramı (Halloween) gibi etkinliklerin fazlasıyla etkilendiklerini ifade etmiştir. Güngör'ün çalışmasında, yaşları 12, 13, 15 olan ABD'deki Türk göçmen çocuklarının, Cadılar Bayramı, Şükran Günü ve yılbaşı

30 M. Gordon Milton, Assimilation in American life, (Oxford University Press, 1964); Tomas Jimenez, The other Side of Assimilation: How Immigrants are Changing American Life, (University of California Press, 2017); Nathan Glazer Daniel Patrick Moynihan, Beyond the Melting Pot: The Negroes, Puerto Ricans, Jews, Italians, and Irish of New York City, (Cambridge, MA: mit Press, 1970); José-Antonio Orosco, Toppling the Melting Pot: Immigration and Multiculturalism in American Pragmatism, (Indiana University Press, 2016).

31 Rachel Lee Rubin - Jeffrey Melnick, "Popular Culture and Immigration", Migrant Marginality: A Transnational Perspective, ed. Philip Kretsedemas v.dğr., (Routledge, 2013), 295.

32 Smith, "Islam in America".

33 Jen'nan Ghazal Read, "Gender, Religious Identity, and Civic Engagement among Arab Muslims in the United States", Sociology of Religion 76/1 (2014): 30-48.

34 Güngör, "Akran Gruplarının Amerikalı Türk Gençlerinin Dini Sosyalleşmelerine Etkileri (12-15 Yaş)”, 226. 
kutlamaları gibi etkinliklere katılmadıklarında arkadaşları arasında mahcubiyet hissettikleri; bazen de o günlerde okula gitmemeyi tercih ettikleri ve bir kısmının da bu günleri Hristiyanlıkla ilgili değil Amerikan kültürüyle ilgili gördükleri bilgisi yer almaktadır. ${ }^{35}$ ABD'de 2015 yılında, The Family \& Youth Institute ve Institute for Social Policy and Understanding tarafından yapılan, ABD'deki Müslüman gençleri kapsayan araştırmada, gençlerin neredeyse yarısının alkol kullandığı, \%25 civarında yasadışı uyuşturucu kullandığı ve yarısından fazlasının evlilik öncesi cinsel ilişkide bulunduğu ifade edilmiştir. Yine aynı araştırmada Müslüman gençlerin cami topluluklarına ve etnik örgütlere ilgi ve katılımının da düşük olduğu tespit edilmiştir. ${ }^{36}$

Yurt dışındaki Türk göçmenlerin en çok zorluk çektiği konulardan biri de cenazelerinin Türkiye'ye getirilmesidir. ABD'de yaşayan Türk göçmenlerin çoğunluğun da cenazelerini Türkiye'de defnetmek istedikleri görülmektedir. ${ }^{37}$ Ancak ABD gibi, uçak yolculuğunun 10-15 saati bulduğu bir ülkeden cenaze nakli Avrupa ülkelerine nispetle daha büyük zorluklar taşımaktadır. Ciddi anlamda maddi külfeti de olan cenaze nakli için DiB'in ABD'de oluşturduğu bir fon bulunmakta ve göçmenler bu fona üye olarak belli bir aidat ödemekte ve cenazeleri olduğunda da kolay ve külfetsiz bir şekilde cenazelerini Türkiye'ye getirebilmektedir.

"Müşavirlik olarak buradaki Türk göçmenlere cenaze hizmeti sunuyoruz. Insanlar cenaze fonuna üye olarak aidat ödüyorlar ve cenazeleri olduğunda müşavirlik olarak cenazelerinin Türkiye gönderilmesine yönelik her türlü hizmeti karşılıyoruz. Aslında cenazelerin burada defnedilmesine yönelik çalışmalarımız var. Çünkü gerçekten çok uzak bir mesafe ve oldukça maliyetli bir iş. Ancak göçmenlerin çoğu cenazelerini Türkiye'ye götürmeyi tercih ediyor. Zamanla bu tercihin de değişebileceğini düşünebiliriz" (Müşavir).

Müşavirliğin cenazelerin ABD'de defnedilmesine yönelik çalışmaları olmasına rağmen Türk göçmenlerin büyük oranda cenazelerini Türkiye getirmek istedikleri anlaşılmaktadır. Ancak ilerleyen süreçte birçok Türk göçmenin, ABD'de kalıcı olmalarını düşünmelerinden ve mezarları daha sık ziyaret edebilme imkânından dolayı cenazelerini $A B D$ 'deki Müslüman mezarlıklarına defnetmeyi tercih edebilecekleri söylenebilir.

Yurt dışı hizmetlerinin genelinde olduğu gibi, ABD'deki din hizmetlerinde de müşavirlikle din görevlileri arasındaki ilişki biçimi ve iletişimin yürütülen din hizmetleri açısından önemli bir konu olduğu söylenebilir.

35 Güngör, “Akran Gruplarının Amerikalı Türk Gençlerinin Dini Sosyalleşmelerine Etkileri (12-15 Yaş)”, 226, 230.

36 Sameera Ahmed v.dğr., "State of American Muslim Youth: Research \& Recommendations", Canton, MI: Institute for Social Policy and Understanding and The Family \& Youth Institute, (2015).

37 Müzeyyen Güler, "Turkish immigrants in the United States: Men, Women and Ghildren", Turkish Migration to the United States: From Ottoman Times to the Present, ed., A. Deniz Balgamis-Kemal H. Karpat, (University of Wisconsin Press, 2008), 170. 
“Din görevlilerinin bize ulaşan problemlerini ivedilikle çözmeye çalışıyoruz. Vizelerin alınması ve uzatılmasında zaman zaman problemler yaşanabiliyor. Din görevlilerinin yabancı dillerini geliştirimlerine büyük önem veriyoruz. Bunun için kurs ücretlerinin tamamını veya önemli bir kısmını müşavirlik olarak karşılamaya çalışıyoruz. Çünkü din görevlilerinin bırakın yabancılarla iletişim kurmasını, yeni nesil Türk göçmenlerle bile iletişim kurmasında İngilizce bilmesi mecburiyet arz ediyor. Çünkü çocukların bir kısmı ya hiç Türkçe bilmiyor ya da Türkçeleri çok yetersiz" (Müş̧avir).

Din görevlileri beş yıl gibi sınırlı bir zaman içinde görev yaptıkları ve bir kısmı da henüz birkaç yıldır ABD'de oldukları için, geçmiş yıllardaki müşavirlik ilişkilerine ve hizmetlerine dair bir değerlendirme yapmamışlar; görev yaptıkları süre içerisinde de müşavirlikle ilişkilerinde bir sıkıntı yaşamadıklarını; istedikleri zaman müşavire ulaşıp problemlerini iletebildiklerini ifade etmişlerdir. Ancak daha önceden $A B D^{\prime}$ de din görevlisi olarak bulunmuş eski din görevlilerinin değerlendirmeleri oldukça dikkat çekicidir.

“Ben geldiğimde ataşeyle falan görüşemiyorduk. Din görevlilerinin birbirleriyle görüşmesini de istemiyorlardı. Buradaki hizmetlerin iyi yürüyebilmesi için müşavir ve ataşenin din görevlileriyle olan ilişkilerinin çok iyi olması gerekiyor. Son dönemde bu ilişkiler epey düzeldi" (G5).

"Bizim görev yaptığımız dönemlerde zaten çok fazla görevli yoktu. O dönemde ben ataşeyle sıkıntılar yaşadım. DiB'in şimdiki hizmetleri eskiye göre daha düzgün. Eskiden müşavirin, ataşenin camiyle, cemaatle irtibatı çok zayıftı. Hele Büyükelçi ve konsolosu camide veya camide düzenlenen bir faaliyette görmeniz imkânsızdı. Son altı yedi senedir durum biraz değişti ama hala çeşitli sıkıntılar var" (G6).

Daha önceden din görevlisi olarak görev yapmış görüşmeciler geçmiş yıllardaki müşavirlikle din görevlileri arasındaki ilişkinin zayıf olması yanında, müşavir ve ataşenin cami hizmetlerine yeterince zaman ayırmadıklarını ifade etmektedir. Yurt dışı hizmetlerinde müşavir ve ataşenin din görevlileriyle olan ilişkilerinin ve camilerde yürütülen hizmetlere yönelik takibinin oldukça önemli olduğu anlaşılmaktadır. Müşavirlikle ilişkiler konusunda dile getirilen bir başka konu ise müşavirlik sekretarya hizmetlerinin yeterli düzeyde olmadığıdır.

“Buradaki en büyük eksiklikten bir tanesi, DiB'in burada iyi bir sekretaryasının olmaması" (G5).

"Müşavirlik bünyesinde verilen sekretarya hizmetleri yeterli değil. Genellikle TACC'daki görevli arkadaşlarla yürütülmeye çalışılıyor ama yeterli olmuyor. Maryland'deki caminin ve külliyenin açılmasından sonra faaliyetlerde büyük bir iyileşmenin olacağını düşünüyorum. Çünkü çok büyük ve içerisinde çok farklı faaliyet alanları ve imkânları olan bir yer olacak" (G12). 
Haftalık hutbeler yanında birçok konunun da müşavirlik tarafından elektronik posta veya telefonla din görevlilerine ulaştırılması gerekmektedir. Bunun yanında Türk ve yabancı birçok kişi de çeşitli konularla ilgili olarak müşavirliği aramaktadır. Dolayısıyla bu durum, mevcut görevleri yanında bir de TACC bünyesinde sekretarya hizmetlerini yürütmeye çalışan görevlilerin iş yükünü artırdığı gibi yürütülen hizmetin de verimliliğini düşürmektedir. Dolaysıyla iyi bir sekretaryanın ABD'de yürütülen din hizmetlerinde önemli olduğu anlaşılmaktadır.

Müşavirlikle ilişkiler bağlamında dile getirilen konulardan biri de, müşavirliğin ve dolayısıyla DiB'in ABD'de yürüttüğü hizmetlerinde bir "geleneğinin olmaması" eleştirisidir. Bu konuyla dolaylı da olsa irtibatlandırılabilecek konulardan biri de cami derneklerinin konumu ve din hizmetlerindeki etkinliğidir.

“DiB'in burada yürüttüğü hizmetlerde bir geleneği yok. Sıkıntı biraz da buradan kaynaklanıyor. Cemaatlerin iyi-kötü bir geleneği var. Bir cemaatte herkes neyin nasıl olacağını biliyor ve tahmin ediyor. DiB burada tamamen eskiden beri cami cemaatinin alışageldiği durumu dikkate alıyor. Mümkün olduğu kadar cami yönetimi ve cemaatiyle bir sürtüşme ve problem yaşanmamasına dikkat ediyor. Dolayısıyla gelen görevli de kendisinden önce oluşan alışkanlıkları gözeterek, cami dernek ve cemaatiyle bir çatışma yaşamadan görev süresini tamamlamaya çalışıyor. Hâlbuki DỉB'in de bir geleneği olmalı. Dỉ'e bağlı camilerde yaşanan problemlerle ilgili çeşitli toplantılar yapılarak, çözümümler üretilebilir" (G2).

"Cami ve dernek faaliyetlerine bir standardın getirilmesi gerekiyor. Her dernek kendi belirlediği şekilde camii işlerini yürütüyor. Yönetim kurulunu kendi istediği şekilde belirliyor. Dernekleri de küstürmeden Müşavirliğin ve Ataşeliğin bu konuyu sadece derneklere bırakmaması gerekir" (G7).

“Görev yaptığım süre içerisinde genel olarak gördüğüm, Diyanetin bir misyon, vizyon problemi veya eksikliği olduğu. Buna özgüven eksikliğini de ekleyebiliriz. Buraya gelen müşavir, ataşe ve din görevlisi neticede kısa bir süreliğine geliyor ve hiç bilmediği bir ortamda görev yapmak durumunda kalıyor. Haliyle mevcut dengeleri gözeterek görevini yapmaya çalışıyor. Böyle olunca da kendisinden önceki uygulamaları olduğu gibi devam ettiriyor. Birçok uygulama camiden camiye değişiyor. Başka dini gruba mensup görevliler adeta kanaat önderi gibi davranıyor. Öz güvenleri daha yüksek. Diyanet bu konuda çalışmalar yapmalı" (G9).

DiB'in ABD'de yürüttüğü hizmetlerde bir "gelenek oluşturamadığı" veya bir "geleneğinin olmadığı" şeklinde ortaya koyulan eleştirinin, DiB'in din görevlisi gönderdiği camilerde daha önceden oluşan yapıyı/alışkanlıkları fazlasıyla dikkate aldığı; müdahale edilmesi gereken bir durum olduğunda dahi çekimser davrandığı şeklinde yorumlanabilir. Durum böyle olunca kısa bir süreliğine yurt dışında görevlendirilen görevlinin de kolay ve sorunsuz bir tavır olarak alışılagelen tutum ve davranışları dikkate aldığı, inisiyatif almaktan çekindiği 
anlaşılmaktadır. Bu durum, DiB'in yürütülen hizmetlerde bir gelenek, tarz ve tavır oluşturamadığı eleştirisiyle birlikle ele alındığında, din görevlisinin toplum içinde bir "kanaat önderi" olamamasının gerekçesi olarak da değerlendirilebilir. Dolayısıyla Dỉ'in, cami dernekleriyle iyi ilişkiler kurmak, mevcut durumu ve alışkanlıkları dikkate almak yanında, din hizmetlerinin daha etkili ve verimli hale gelmesi ve din görevlilerinin etkisinin arttırılması konusunu ele almasının yurt dışı hizmetlerinde verimliliği arttırabileceği söylenebilir.

DiB'in yurt dışı hizmetlerinde en önemli paydaşının cami dernekleri olduğu bilinmektedir. Dernekler caminin yapım, satın alma ve bakım işlerinden cami lojmanlarına ve din görevlisinin vize işlemlerine kadar birçok işle ilgilenmekte; ayrıca bir sivil toplum örgütü olarak kabul görmektedir. Yurt dışında cami dernek başkanı olmanın ve dernek yönetiminde yer almanın önemli bir statü olarak değerlendirildiğini de eklemek gerekir. ${ }^{38}$ Bu durum yurt dışındaki cami derneklerini güçlü bir konuma getirmekte ve zaman zaman Dỉ'le ve din görevlileriyle sürtüşmelerin yaşanmasına neden olabilmektedir. Bu durumun ABD'deki başka Müslüman toplumlarda da söz konusu olduğu görülmektedir. Abuelezz'in araştırmasında ABD'de görev yapan imamların cami yönetimleri ile zaman zaman problemler yaşadıkları belirtilmiştir. ${ }^{39}$

\subsection{Camilerde Çocuklara Yönelik Dini Eğitim Faaliyetleri ve Okul Talebi}

ABD'de özellikle kırsal kökenli Türk göçmenlerin yeni nesillere dini eğitim verilmesini önemsedikleri ve bu konuda Dỉ'den büyük bir beklenti içinde oldukları söylenebilir. Yurt dışında yeni nesillerin dini sosyalleşmesinde en önemli araçlardan birinin din eğitimi veren dini merkezler ve camiler olduğu, ABD'de de bu görevi büyük oranda DiB'e bağlı camilerin üstlendiği görülmektedir. ${ }^{40}$ ABD'deki camilerin büyük çoğunluğunda çocuklara ve gençlere yönelik eğitim programları uygulandığı gibi, ${ }^{41}$ hafta sonları ve çeşitli tatil zamanlarında Dỉ'e bağlı camilerde de çocuklara ve gençlere yönelik dini eğitim verilmekte; başta Kur'an-ı Kerim ve namaz sureleri olmak üzere temel düzeyde İslam'ın inanç ve ibadetleri öğretilmektedir.

“Hafta sonu yaklaşık altmış öğrenci oluyor. Tek bir hocanın bu kadar öğrenciyle başa çıkması çok zor. Çocuklar burada oldukça rahat ve çok hareketli. Okullarındaki sınıflarında dolaşabiliyorlar. Müfredatları oldukça hafif. Dolayısıyla camiye geldiklerinde de bu rahat tavırlarını devam ettiriyorlar. Amerikan güreşine benzer boğuşmalar çok yaygın. Artık televizyonlardan veya şiddet içerikli bilgisayar

38 Ahmet Onay, "Batı'da Sosyal Çevre ve Din, Danimarka'da Müslüman Türk Toplumu”, Değerler Eğitimi Dergisi 15/33 (2017): 155.

39 Muhammed Abuelezz, A Survey of American Imams: Duties, Qualifications and Challenges: a Quantitative and Religious Analysis, (Doctoral dissertation, University of Georgia, 2011), 145.

40 Güngör, "1.5 ve 2. Nesil Türk Gençlerinin Ailede Dini Sosyalleşmeleri: New Jersey, USA Örneği", 87.

41 Ihsan Bagby, "The American Mosque: Activities, Administration, and Vitality of the American Mosque: Report Number 2 from the US Mosque Study 2011", Institute of Religion Study, 2012. 
oyunlarından mı etkileniyorlar bilmiyorum. Çocuklara bir şey diyemiyoruz. Öz güvenleri çok fazla. Sesimizi biraz yükseltsek, 'sen bana bu şekilde konuşamazsın', diyor. Diğer taraftan öğretebildiğimiz dini bilgiler çok basit düzeyde. Bir kısım öğrenciye Kur'an- Kerim'i yüzünden okumayı öğretiyoruz. Aileler de buna önem veriyorlar. Çocukların Kur'an-ı Kerim okuyabilmesini istiyorlar. Namaz surelerini ise kısmen ezberletebiliyoruz" (G1).

"Hafta sonları ve tatillerde çocuk okutuyoruz ama çocuklarla yeterince ilgilenemiyoruz. Özellikle tatillerde öğrenci sayısı artıyor. Çocuklar hafta sonu bir veya iki gün geliyor. Tek bir hocayla sayıları bazen 50-60'ı bulan öğrencilerle baş etmek kolay olmuyor. Diyanet en azından öğrencinin fazla olduğu yaz dönemlerinde hoca takviyesi yapabilir. Bu hocalar daha önce burada görev yapmış hocalardan da seçilebilir" (G2).

"Hafta sonları ve yazları çocuklara yönelik kurslarımız var ama çocukların ilgisi çok zayıf. Burada doğup-büyüyen çocukların ilgisini nasıl çekebileceğimizi bilemiyoruz. Çocuklar çok ilgisiz. Zoraki geliyorlar. Aile ilgisi de çok düşük. Getirip bırakıyor o kadar. Çocuklara yeterince zaman ayıramıyoruz. Bir hocayla bir öğrenciye en fazla on dakika zaman ayırabiliyoruz. Camilerde çocukların oyun oynayabilecekleri alanlar yok. Çocuklar sıkılıyorlar. Bir de masa-sandalyede oturmaya alışkınlar. Cami ortamında rahat edemiyorlar. Çocuklar aşırı hareketli. Kendi aralarında güreşiyorlar, boğuşuyorlar" (G4).

"Yetişkin cemaate karşı yürütülen hizmetlerde çok problem yok belki ama yeni yetişen nesle ve çocuklara yönelik Diyanet hizmetleri çok yetersiz. Tek bir hoca yeterli gelmiyor" (G6).

"Hem Türk göçmenlerin hem de dernek yetkililerinin en büyük beklentisi çocukların dini eğitimine yönelik. Aileler bu konuda çocuklarına yardımcı olamıyor. Hem vakitleri olmuyor hem de yeterli bilgileri olmayabiliyor. Bazen namaz surelerini evdeki kişilerle tekrar etmelerini istediğimizde, evde yaşlı insan yoksa bazı çocukların zorluk çektiklerini bile görüyoruz. Öğrenci yoğunluğu olan bölgelerde ek görevli talebi olabiliyor. Başkanlığımız maaşını dernek ödemesi kaydıyla görevli gönderiyor. Bazı dernekler sırf bu yüzden kabul etmek istemiyor. Tabi bu durumdan en fazla din görevlisi ve yeterli eğitimi alamayan öğrenciler etkileniyor. En azından Başkanlığımız maaşını ödeyip, dernek de kalacak yer ayarlayarak bunu çözebilir" (G7).

"Burada en değerli şey zaman. İnsanlar iş yoğunluğundan dolayı ailelerine, çocuklarına yeterince zaman ayıramıyor. Bir taraftan da çocuklarının kendi inanç ve kültürlerini öğrenmelerini istiyorlar. Tabi bu bütün Türk göçmenleri kapsayan bir durum olmayabilir. Din görevlisi olarak biz genelde bizimle irtibat kuran, en azından yılda birkaç defa da olsa camiye gelen insanların görüşlerini biliyoruz. Dolayısıyla bu durum bize yönelik beklentileri de arttırıyor. İnsanlar çocuğuna bütün dini ve kültürel bilgilerin camide verilmesini istiyor ancak bunun tek 
hocayla karşılanabilmesi çok zor. Özellikle yaz mevsiminde öğrenci sayısı daha da artıyor" (G9).

"Cemaati ve çocuk sayısı kalabalık camilerde tek görevli yeterli olmuyor. Cami dışında da birçok program oluyor ve din görevlisinin bunlara katılması gerekiyor. Burada mesafeler çok uzak, o yüzden bir programa katılmak çok zaman alıyor" (G13).

"Tatil zamanları daha çok öğrenci geliyor. Bizim camimizde kadın hoca olduğu için kız ve erkek öğrencileri ayırıyoruz. Kadın hocanın olmadığı camilerde iş daha da zor. Dolayısıyla en azından öğrencinin yoğun olduğu zamanlarda hoca sayısının artırılması gerekiyor" (G14).

Göçmen ailelerinin çoğu din görevlisinin ve camideki hizmetlerin iyi veya kötü olmasını çocuğunun camide aldığı eğitim üzerinden değerlendirmekte; özellikle Kur'an-ı Kerim okumasını öğrenen, namaz surelerini ezberleyen ve temel bilgileri öğrendiğini ortaya koyan çocukların ailelerinde din görevlisi ve cami hizmetlerine yönelik memnuniyetin arttığı ifade edilmektedir. Dolayısıyla bu durum, camideki dini eğitime yönelik beklentiyi de arttırmaktadır. Din görevlileri ailelerin beklentileri yanında katkılarının az olduğuna ve görevli sayısının yetersizliğine dikkat çekmiştir. Benzer şekilde, Almanya'da yapılan bir araştırmada da din görevlilerinin ailelerin din hizmetlerinden beklentilerinin çok yüksek, ancak çocuklarının eğitimiyle ilgilenme oranlarının çok düşük olduğunu belirttikleri tespit edilmiş, velilerin çocuklarıyla yeterince ilgilenmediğini düşünen din görevlilerinin oranının \%90 civarında olduğu tespit edilmiştir. ${ }^{42}$

Camilerde çocuklara verilen eğitimde din görevlisi sayısının yeterli olmadığı ifade edilmiştir. İsveç'te Türk göçmenler ürerine yapılan araştırmada da, yapılan kurs faaliyetlerinin dersler, yer, zaman ve din görevlilerinin yeterliliği bakımından ihtiyacı karşılayabilecek durumda olmadığı tespit edilmiştir. ${ }^{43}$ Dolayısıyla görüşmecilerin dile getirdiği problemlere benzer problemlerin DiB'in yurt dışında faaliyet yürüttüğü farklı ülkelerde de olduğu görülmektedir. Bu bakımdan çocukların yoğun katılımının olduğu dönemlerde mevcut din görevlisine yardımcı olabilecek, dini ve pedagojik formasyonu olan kişilere ihtiyaç duyulduğu anlaşılmaktadır.

Görüşmecilerin dile getirdiği bir başka konu ise, özellikle yeni nesle verilen dini eğitimde dinin duygu ve düşünce boyutuna yönelik bir aktarımın yapılamadığı yönündedir.

"Çocuklara dini duygu ve düşünce aktaramıyoruz. Camide verdiğimiz eğitim namaz sureleri ve çok az dini bilginin öğretilmesiyle sınırı" (G1).

42 Fatma Latifoğlu, "Yurt Dışında Görev Yapan Din Görevlilerinin Problemleri: Almanya Örneği”, PESA Uluslararası Sosyal Araştırmalar Dergisi 1/2 (2016): 8, 12.

43 Arif Korkmaz, Göç ve Din, (Konya: Çizgi Kitabevi, 2017), 366, 411. 
"Çocuklara az da olsa dini bilgi aktarabiliyoruz belki ama dini duygu, düşünce ve davranış kazandıramıyoruz" (G4).

"Çocuklara Türkçe olarak çok basit düzeyde dini bilgi aktarmakta bile zorlanıyoruz ki dini duygu ve düşünceyi nasıl aktarabilelim? Çocukların bize sordukları sorulara veya kafalarındaki şüphelere cevap veremiyoruz. Onların Türkçeleri bizim de İngilizcemiz yeterli değil" (G9).

“Dini düşünce konusunda buradaki çocuklara Türkçe olarak bir şey anlatmak neredeyse imkânsız. Hristiyanlığın hâkim olduğu bir ülkede yaşıyorlar ve burada eğitim alıyorlar. Müslüman olduklarını, farklı olduklarını biliyorlar. Bazı şeyleri sorguluyorlar, mukayese ediyorlar ama dinin düşünce kısmı ancak kendi anladıkları dilde yani İngilizce olarak anlatılabilir" (G14).

Türk göçmenlerin ABD'de doğan çocuklarının bir kısmı hiç Türkçe bilmemekte, bir kısmı ise ancak basit düzeyde bir iletişim kurabilecek kadar Türkçe bilmektedir. Bu durum başka ülkelerdeki Türk göçmenlerin yeni nesilleri için de benzerlik göstermektedir. Nitekim Almanya'da Türkgöçmenler üzerineyapılan çalışmalarda ikinci ve üçüncü nesilde Türkçenin oldukça yetersiz olduğu tespit edilmiştir. ${ }^{44}$ Bu durumda yurt dışında doğup büyüyen yeni nesle dinin duygu ve düşünce yönünü Türkçe olarak aktarabilmenin çok zor olduğu anlaşılmaktadır. ${ }^{45}$ Dini ve kültürel konuların İngilizce olarak anlatılması ise orta veya iyi düzeyde İngilizce bilgisini gerektirmektedir ki bu da görüşmecilerin ifadelerinden anlaşıldığı gibi mevcut din görevlileri için mümkün görünmemektedir. Bu durumda ABD'de Dỉ'in camilerde çocuklara verdiği din eğitimi Kur'an-ı Kerim okumayı öğretme, namaz surelerinin ezberletilmesi, abdest ve namaz konularıyla sınırlı kalmakta; dinin duygu, düşünce ve sosyolojik boyutuna yönelik bir bilgilendirme söz konusu olamamaktadır. Bu durumun DiB'in yurt dışındaki din eğitiminde ciddi bir eksiklik oluşturduğu ve yine DiB tarafından çok boyutlu bir konu olarak değerlendirilmeye alınması gerektiği söylenebilir.

Görüşmecilerin dile getirdiği bir başka konu ise, camilerde yürütülen eğitim faaliyetlerinde yeterli İngilizce kaynak olmamasıdır.

"Bir diğer problem de İngilizce kaynak olmaması. İnanç, ibadet ve ahlak konusunda bizim öğrencilerimizin anlayacağı şekilde İngilizce kaynaklara ihtiyacımız var. Biz haliyle Türkçe anlatıyoruz ama çocukların çoğu anlamıyor. ABD'de çok sayıda Mısır, Pakistan gibi Müslüman toplumlara ait cami ve okullar var. Cami ve okullarında İngilizceyi kullanıyorlar. Bizim elimizde ise İngilizce kaynaklar mevcut değil" (G1).

44 Celalettin Çelik, "Almanya'da Türkler: Sürekli Yabancllık, Kültürel Çatışma ve Din”. Milel ve Nihal İnanç, Kültür ve Mitoloji Araştırmaları Dergisi 5/3 (2008): 129-130; Emel Yiğittürk Ekiyor, “Ulusaşırı Bağlar ve Dil: ABD’de Yaşayan Türkler Örneği", Avrasya Sosyal ve Ekonomi Araştırmaları Dergisi (ASEAD) 5/2 (2018): 49.

45 Güngör, "Amerika'da Türkler ve Türklerin Dini Kurumsallaşmaları Açısından Camiler", 97. 
"Ingilizce dini kaynak sıkıntımız var. Dini bilgiler veren, başta peygamberlerin hayatı olmak üzere dini hikâyeler anlatan Ingilizce kaynakların olması lazım" (G3).

"Çocukların dini bilgileri öğrenebilecekleri İngilizce kaynağa intiyaç var" (G6).

"Ingilizce kaynak sıkıntısı çekiyoruz, çocuklara verebileceğimiz yeterli kaynağımız yok" (G12).

"Çocukların ve gençlerin dini ve kültürel değerlerimizi öğrenebilecekleri Ingilizce kaynaklar yeterli değil. Buradaki çocukların anlayabilecekleri şekilde, uzman kişiler tarafından hazırlanacak her tür İngilizce kaynağa ihtiyaç var" (G14).

ABD'de yaşayan Türk göçmenlerde Türkçe'nin ikinci ve sonraki kuşaklara aktarımının giderek azaldığı ve ABD'de doğup büyüyen çocukların Türkçe okuma ve anlama becerilerinin çok yetersiz olduğu bilinmektedir. ${ }^{46}$ Dolayısıyla camilerde dini eğitimde kullanılan Türkçe kaynakların çocuklar için yeterli faydayı sağlamadığı, okuyup anlayabildikleri dil olan İngilizcede ise DiB tarafından hazırlanmış kaynakların ise yetersiz olduğu görülmektedir. ${ }^{47} \mathrm{DiB}^{\prime}$ in yurt dışında yürüttüğü din hizmetlerinde kaynak ve materyal eksikliği, Almanya'da din görevlilerinin görüşlerinin yer aldığı araştırmada da ciddi bir eksiklik olarak vurgulanmış; din görevlilerinin materyalleri yetersiz bulma oranı \%71 civarında tespit edilmiştir. ${ }^{48}$ Korkmaz'ın İsveç'teki araştırmasında da genç göçmen kuşakların Türkçe bilgisinin yetersiz olduğu ve bu yüzden DiB'in ev sahibi ülkenin dilinde yazılı, görsel ve işitsel yayınlar hazırlamasının faydalı olacağı ifade dilmiştir. ${ }^{49}$ DiB'in yurt dışında yürüttüğü din hizmetlerinde, o ülkenin diline ait kaynak eksikliğinin genel bir problem olduğu anlaşılmaktadır. Dolayısıyla Dỉ'in çocukların $A B D$ 'deki eğitim ortamındaki alışkanlıklarını ve öğrenme pratiklerini de dikkate alarak İngilizce yazııı ve görsel kaynaklar hazırlamasının camilerde yürütülen dini eğitimi daha verimli hale getireceği; bu kaynakların aynı zamanda Türkçe ve Ingilizce olarak iki dilli olarak hazırlanmasının ve çocukların aynı sayfa içinde veya görsel kaynaklarda alt yazı olarak Türkçe ifadeleri de görmelerinin Türkçelerine de katkı sağlayacağı söylenebilir.

DIB 2015 yılı yaz ayında ABD'deki Türk göçmenlerin çocuklarına yönelik Bursa ilinde bir yaz kampı projesi uygulamıştır. Üç haftalık kampla ilgili oldukça olumlu sayılabilecek değerlendirmeler yanında eleştiriler de ortaya koyulmuştur.

"Diyanetin buradaki çocuklara ve gençlere yönelik Türkiye'de uyguladığı üç haftalık program çok faydalı oldu. Fakat sanıım kalma şartları çok iyi ayarlanamamış. Çocuklardan kalma şartlarına yönelik şikâyetler geldi" (G7).

46 Yiğittürk Ekiyor, "Ulusaşırı Bağlar ve Dil: ABD'de Yaşayan Türkler Örneği", 49.

47 Güngör, "Amerika'da Türkler ve Türklerin Dini Kurumsallaşmaları Açısından Camiler", 97.

48 Latifoğlu, "Yurt Dışında Görev Yapan Din Görevlilerinin Problemleri: Almanya Örneği", 11.

49 Korkmaz, Göç ve Din, 401. 
“Türkiye'de yapılan programlar aslında çok etkili olabilir. Fakat çok iyi planlanması ve çocukları memnun edecek şartlarda yapılması gerekir. Nitekim çok iyi düşünülmüş olmasına rağmen, üç haftalık programa katılan öğrencilerin kalma şartlarından pek memnun olmadıkları görüldü” (G14).

DiB'in Türk göçmenlerin çocuklarına yönelik Türkiye'de gezi ve eğitim programları uygulamasının olumlu bulunduğu anlaşılmaktadır. Ancak 2015 yılında Bursa ilinde yapılan yaz kampında, ilk olmasından da kaynaklanan bazı olumsuzlukların yaşandığı ifade edilmiştir. Türkiye'nin çeşitli şehirlerinde çocuklara ve gençlere yönelik düzenlenecek gezi ve eğitim programlarının eğitim yanında kendi ülkelerini tanımak anlamında da ciddi etkisinin olacağı söylenebilir.

Görüşmecilerin çocukların eğitimi ile ilgili olarak dile getirdiği bir başka konu ise, Türk göçmenlerin çocuklara yönelik dini eğitim yanında Türkçe ve tarih gibi alanlarda da derslerin verilmesi ve hatta mümkünse DiB'in öncülüğünde okullar açılmasıdır.

"Camilerde ayrıca Türkçe ve tarih dersleri verilmeli. Bunları din görevlilerin vermesi mümkün değil. Din eğitimine bile yeterli zaman bulamıyoruz. Bu konularda uzman kişiler olmalı" (G2).

"DiB yaz aylarında ilahiyat hocalarını seferber etmeli. Bir irşat ekibi oluşturulmalı. İslam tarihi, Osmanlı tarihi konusuna da ayrıca ağırlık verilmeli. Buradaki Arap, Pakistan vs. menşeli Müslüman milletlerin camileri olduğu gibi, hepsinin okulları ve "islamic center" ları var" (G5).

"Türkçe ve tarih alanlarında da hocaya ihtiyaç var. Din görevlisi dini bilgileri bile vermede zorlanıyor. Yeterli zaman bulamıyor. Ayrıca camilerin eğitim için sahip olduğu alanlar da yetersiz. Caminin bünyesinde bir okulun olması gerekiyor" (G6).

"Insanların bize ilettikleri en önemli konulardan biri devletin burada okul açması. Birçok Müslüman toplumun burada okulları var. Bu konunun çok detaylı bir şekilde ele alınması gerekiyor. Diyanetin neden burada okul açmadığı şeklinde sorularla çok karşılaşıyoruz" (G14).

ABD’ye, Avrupa'ya olduğu gibi Millî Eğitim Bakanlığı üzerinden öğretmen gönderimi söz konusu olmadığı için çocukların okullarda seçmeli olarak Türkçe dersi alabilmeleri mümkün olamamaktadır. Göçmenlerin, çocuklarının Türkçe ve tarih gibi konularda ders almalarına yönelik camilerden ve din görevlilerinden bir beklenti içinde oldukları ifade edilmektedir. ABD'de Türk göçmenlerin dini ve kültürel talepleri konusunda muhatap aldığı ve bildiği tek devlet kurumu DỉB'dir. Dolayısıyla çocuklarının eğitimi konusunda kendilerine okul hizmeti sunabilecek bir kurum olarak DiB'i gördükleri anlaşılmaktadır. ABD'de Dỉ'e bağlı, New Jersey/Monroeville Murat Camii gibi bazı camilerin okul konusunda çok elverişli 
arazilere sahip olduğu bilinmektedir. Dolayısıyla DiB'in, ilişkili olduğu Türkiye Diyanet Vakfı üzerinden, başta Milli Eğitim Bakanlığı olmak üzere devletin ilgili kurumlarıyla da ilişki içerisinde $A B D$ 'de, içerisinde dini eğimin de verildiği okul projeleri geliştirebileceği söylenebilir.

Camilerdeki dini eğitimle ilgili dile getirilen konulardan biri de camilerde yatılı eğitim imkânının olmamasıdır.

“Bu bölgede Diyanetin dışında yatılı olarak dini eğitim veren bir kurum var. Yatılı kalmak istemeyen öğrencilere yönelik de servis hizmetleri var. Servis, sabah öğlencileri alıyor, akşam evlerine bırakıyor. Günlük yemek piştiği için de çocuklar yemek problemi yaşamıyor ve akşama kadar kalabiliyorlar. Diyanetin yatılı eğitimi daha kapsamlı ve farklı aktivitelerin olduğu bir mekân olarak tasarlanabilirse çok faydalı olur" (G9).

"Yatılı eğitim olmayınca zor. Yatılı eğitim imkânı olan Türkiye kökenli dini grupların avantajı da bu. Ellerinde hem yetişmiş kadro hem de yatılı mekan imkânları var. Diyanetin Brooklyn'de böyle bir çalışması var sanırım, yatılı kurs açılması planlanıyor" (G10).

Çocukların hafta sonları ve tatil zamanlarında camilerde aldığı dini eğitimin hem çocukların ulaşımı hem de zaman darlığından dolayı verimli olmadığı anlaşılmaktadır. Dolayısıyla din görevlilerinin, camilerde verilen dini eğitimde verimliliğin arttırılması konusunda dile getirdikleri konulardan biri de yatılı eğitim verilebilecek bir ortamın hazırlanmasıdır. Yatılı eğitimle çocuklara daha fazla zaman ayrılabileceği, daha iyi eğitim ve sosyalleşme imkânı sunulabileceğinin öngörüldüğü anlaşılmaktadır.

\subsection{Kadın Din Görevlileri}

Yurt dışı DiB hizmetlerinde erkek din görevlilerinin yanında kadın din görevlileri de görev yapmaktadır. Kadın din görevlileri genellikle din görevlisi olarak yurt dışı görevinde bulunan erkek din görevlilerinin eşi olup, ya aynı şekilde yurt dışı sınavını kazanarak ya da yurt dışı maaşı almadan sadece Türkiye'deki maaşıyla görev yapmaktadır. Araştırmanın yapıldığı tarih itibariyle kadın din görevlisi sayısı dörttür. Bu görevlilerden biri TACC merkezinde görev yaparken diğerleri eşlerinin görev yaptığı camilerde görev yapmaktadır. Bu görevlilerden iki tanesiyle yapılan görüşmelerde ABD'deki DiB hizmetlerinde kadın din görevlisine duyulan ihtiyaca dikkat çekilmiş ve aynı şekilde başta Müşavir olmak üzere diğer din görevlileri de kadın din görevlisi sayısının arttırılması gerektiğini ifade etmiştir.

"Buraya gelen din görevlilerinin mutlaka bay-bayan olarak gelmesi gerekmektedir" (G2).

“Kadınlara yönelik hizmetlerde eskiden beri gelen bir eksiklik ve ihmal var. Bu konu üzerinde önemle durulmalı. Bu bakımdan kadın hocaların olması ve sayılarının arttırılması gerekiyor" (G5). 
“Kadın din görevlilerinin gelmesi çok olumlu oldu. Diyanet ABD'deki din hizmetleri konusunda çok geç kaldı ama kadın hoca gönderilmesi konusunda daha da geç kalındı. Umarım bundan sonra sayıları artar ve en azından her camide bir kadın hoca bulunur" (G6).

"Cemaati az olsun çok olsun muhakkak kadın görevlinin gelmesi gerekiyor. Amerika'ya görevli belirlerken çift görevli olması muhakkak göz önünde bulundurulmalı. Kadınlarla ilgilenilmediği takdirde oluşan boşluğu farklı dini gruplar dolduruyor. Kadınlar erkeklerden daha aktif. Haftalık ev toplantıları yapıp Kur'an okuyorlar. Bunun yanında bebek mevlitleri, vefat edenlerin yıldönümleri gibi programlar yapılıyor. Kadın din görevlisi bu konuda aktif olduğu takdirde kesinlikle Diyanetin görevlisini tercih ediyorlar. Camide yapılacak programların organizasyonunda çoğu zaman kadınların yardımı daha fazla oluyor. Camii cemaatinin toplanması ve bir arada tutulmasında kadın din görevlisi önemli. Sadece erkek görevli olduğu takdirde bütün ailelerle yeteri kadar iletişim kurulamıyor. Kadın din görevlisi olduğu zaman ailelerle iletişim daha çabuk ve kolay oluyor" (G8).

"Kadın hoca ihtiyacı çok fazla. Kadınlar uzun yıllar ihmal edilmiş. Esasen ABD'deki görevli sayısı zaten yetersiz ve kadın din görevlisi ise çok az" (G12).

"Camilerde kadın din görevlisi olması çok önemli. Yıllardır inmal edilmiş bir konu" (G14).

ABD'de kadın din görevlisinin Dỉ'in hizmetlerinde önemi bir yerinin olduğu ancak mevcut sayının yeterli görülmediği anlaşılmaktadır. Almanya'da yapılan araştırmada da din görevlilerinin \%70 oranında, kadın din görevlisi sayısının ihtiyacı karşılamaktan uzak olduğu görüşünde oldukları tespit edilmiştir. ${ }^{50}$ Müşavir de kadın din görevlisinin din hizmetlerinde önemli bir yerinin olduğunu ve mevcut sayıyı arttırmaya çalıştıklarını; gelen erkek görevlilerinin eşlerinin DiB'de görevli olması durumunda görevlendirme yoluna gittiklerini ifade etmiştir.

Kadın din görevlilerinin, Türk göçmenlerin önemli sosyalleşme alanlarından biri olan camilerde kadınlara yönelik çok çeşitli program ve faaliyetler düzenlediği; camiye dini eğitim almak için gelen çocuklara ve yetişkin kadınlara ders verdiği ve aynı zamanda kadınların ev ve salon gibi mekânlardaki etkinliklerine katılarak göçmen kadınlar arasındaki dayanışmaya katkı sağladığı görülmektedir. Bu bakımdan ABD'deki din hizmetlerinde kadın din görevlisi sayısının arttırılmasının önemli görüldüğü anlaşılmaktadır.

\subsection{Uluslararası İlahiyat Projesi}

Görüşmelerde, Dỉ'in yurtdışındaki cami hizmetlerinde o ülkedeki göçmen çocukların yetiştirilerek din hizmetlerinde istidam etmesine yönelik hazırladığı "Uluslararası Illahiyat Projesi" de gündeme gelmiştir.

50 Latifoğlu, "Yurt Dışında Görev Yapan Din Görevlilerinin Problemleri: Almanya Örneği", 11. 
"Uluslararası İlahiyat Projesi bence tam bir fiyasko oldu. Olmayacak bir projeydi. Amerikan kültüründe yetişmiş, lise eğitimi görmüş çocukları buradan alıp Türkiye'de İlahiyat okumaya götürmekten hiçbir sonuç elde edilemedi. Bu çocukların çoğunluğu okuyamadan, oraya alışamadan geri döndüler" (G5).

"Bizim camimizden de bir kişi gitti. Ben de gitmesini teşvik ettim ancak bir süre sonra geri döndü. Çocukların burada yetiştiği şartlar çok farklı. Çok farklı bir eğitim sistemi içerisinde yetişiyorlar. Döndüğünde, alışamadığını, uyum sağlayamadığını söyledi" (G7).

“Diyanetin Uluslararası İlahiyat Projesine bu bölgeden de gidenler oldu. Ancak biri uyum sağlayamadı ve geri döndü. Diğeri ise zorlanarak da olsa bu sene bitirecek. Burada doğup büyüyen çocukların bu tür bir programa uyum sağlayabilmeleri çok zor" (G11).

"Aslında bakıldığı zaman İlahiyat projesi iyi bir proje. Burayı bilen insanlar din eğitimi alarak buradaki insanlara daha iyi hizmet verebilirler. Ancak burada doğup-büyümüş, eğitim almış bir insanın Türkiye'deki bir eğitim sistemi içerisinde, üstelik dini bir eğitime uyum sağlayabilmesi çok zor. Nitekim gidenlerin çoğu uyum sağlayamadı ve geri döndü" (G14).

Uluslararası Illahiyat Programı, 2006 yılında, bu amaçla, yurtdışında yaşayan Türk göçmenlerin çocuklarına Türkiye'de dini yükseköğrenim imkânı sağlamak üzere DiB'in desteklediği ve koordine ettiği bir program olarak hayata geçmiştir. Program, başta Avrupa ülkeleri olmak üzere $A B D$ ve Avustralya gibi Türk göçmenlerin yaşadığı ülkelerde lise öğrenimini tamamlamış ve bulunduğu ülkenin vatandaşı olan öğrencilerin, Türkiye'deki ilahiyat fakültelerinde lisans düzeyinde dini yükseköğrenim görmelerini amaçlamaktadır. ${ }^{51} \mathrm{Bu}$ şekilde hem yurt dışı din hizmetlerinde o ülkede yetişmiş insanların daha verimli ve kalıcı olacağıöngörülürken aynı zamanda yurt dışındakigöçmenler arasında dini yüksek eğitimli insan sayısını arttırmanın da amaçlandığı anlaşılmaktadır. Araştırmanın yapıldığı 2015 yılı itibariyle bu programa ABD'den katılan öğrenci sayısı on yedidir. ${ }^{52}$ Ancak yurt dışından bu programa katılan öğrencilerden bir kısmının dil ve uyum sağlayamama gibi problemlerden dolayı geri döndükleri; programın başladığı 2006 yılından 2012 yılına kadar programa katılan öğrencilerden elli bir kişinin programa devam etmediği tespit edilmiştir. ${ }^{53}$

Din görevlilerinin Uluslararası İlahiyat Projesine olumlu bakmalarının yanında uygulanabilirliği konusunda kötümser olduğu; $A B D^{\prime}$ de doğmuş büyümüş ve üniversite eğitimine kadar olan süreci $A B D^{\prime}$ de tamamlamış bir gencin Türkiye

51 İsmail Erşahin, "Bir Diyanet Projesi Olarak Uluslararası Illahiyat Programı”, Diyanet Illmi Dergi 51/2 (2015): 125-146; Nurettin Gemici, “Uluslararası İlahiyat Projesi ve Diyanet İşleri Türk-İslam Birliği (DiTiB)'nin Almanya'daki Din Hizmetlerine Katkısı", Değerler Eğitimi Dergisi 13/30 (2015): 181-211.

52 Erşahin, "Bir Diyanet Projesi Olarak Uluslararası Ilahiyat Programı”, 135.

53 Erşahin, "Bir Diyanet Projesi Olarak Uluslararası Illahiyat Programı”, 141. 
şartlarında bir üniversite ortamına alışmasının zorluğu yanında, daha önce neredeyse hiç bilmediği ilahiyat gibi bir alanda eğitim alabilmesinin ciddi zorluklar barındırdığı anlaşılmaktadır. Ancak programın daha da geliştirilerek uzun vadede yurt dışındaki göçmenlerin dini ve kültürel hayatına olumlu katkılar sağlayacağı söylenebilir. Korkmaz'ın çalışmasında da programın sürdürülmesi gerektiği ifade edilmiştir. ${ }^{54}$ Esasen $A B D^{\prime}$ de yaşayan farklı milletlere mensup Müslümanların genelinde imamların görevleri ve eğitimleriyle ilgili ciddi tartışıların devam ettiğini belirtmek gerekir. ${ }^{55}$

\subsection{Din Görevlilerinin Dil Problemi}

Görüşmelerde dile getirilen konulardan biri de, ABD'de görev yapan din görevlilerinin yabancı dil konusudur.

"Ingilizce bilmek büyük avantaj elbette. Aslında bazı durumlarda bir zorunluluk olarak da karşımıza çıkıyor. Çocuklar ve gençler dinle ilgili ve özellikle de Hıristiyanlıkla ilgili birçok soru soruyorlar. Bazen, 'ne biliyorsun hocam, belki onların ki doğrudur', diyen çocuklar da oluyor. Diğer taraftan kabir hayatı ve cinler gibi konularla ilgili sorularda soruyorlar. Son zamanlarda haberlerde veya internet sitlerinde yer alan Müslüman görünümlü terör örgütleri ve eylemleriyle ilgili de sorular geliyor. İngilizce yetersiz olunca bu tür sorulara verilen Türkçe cevapları anlayamıyorlar" (G1).

"Yeterli düzeyde İngilizce bilmeyince çocuklarla iletişim kurmak zorlaşıyor. Annesi yabancı olan veya anne-babanın Türk olduğu halde hiç Türkçe bilmeyen çocuklar var. Burada doğan çocukların bildiği ve anladığı Türkçeyle onlara dini bir konuyu ve özellikle de ahlaki konuları anlatmak çok zor. Örnek vermeniz ve açıklama yapmanız gerekiyor. Ne kadar basitleştirseniz de anlamıyorlar. Çocuklarla iletişim ciddi bir problem ve bu problem gittikçe artacak gibi" (G2).

“Türkçe olarak buradaki çocuklara din görevlilerinin dini duygu ve düşünce aktarması imkânsız. Ancak çok basit ifadeleri anlayabiliyorlar" (G3).

“Burada din görevlisinin İngilizce bilmesi büyük bir avantaj. Ancak gelmeden önce belirli düzeyde İngilizcesi olmayan kişi için burada bir seviye elde etmek kolay değil. İngilizce bilmek çocuklarla iletişim kurmada da çok faydalı oluyor. Tabi kimi veli çocuklarının camide aynı zamanda Türkçelerinin de gelişmesini istiyor. Ama çocuklar kendi aralarında mutlaka İngilizce konuşuyorlar" (G9).

"Çocuklarla iletişim kurmak kolay değil. Çoğunun Türkçesi çok yetersiz. Çok az da olsa dua ve sureleri ezberletebiliyoruz. Ama dini bilgi ve düşünce kazandıramıyoruz. Bunun için yeterli düzeyde İngilizce bilmek gerekiyor. Bizim

54 Korkmaz, Göç ve Din, 400.

55 Abuelezz, A Survey of American Imams: Duties, Qualifications and Challenges: a Quantitative and Religious Analysis, 45. 
dışımızdaki Müslüman toplumlarda hem cami hizmetlerinde hem de eğitim alanında tamamen İngilizce kullanılıyor" (G11).

“Din görevlisinin dil bilmesi çok önemli. Hele bazı camilerde dil bilmeden görev yapmak çok zor. Özellikle Maryland'deki cami bu açıdan çok önemli ki, açılışından sonra birçok yabancı Müslümanın buraya gelmesi bekleniyor" (G13).

“Din görevlisinin İngilizce bilmesi elbette çok önemli. Yeni neslin çoğu Türkçe bilmiyor. İngilizce bilmeyince de sizinle konuşmak istemiyor" (G14).

Dỉ'de yurtdışına gönderilecek din görevlilerinden, gönderilecekleri ülkenin dilini bilmeleri veya o dile ait bir belgeye sahip olmaları şartı aranmamaktadır. Görüşmelerden de din görevlilerinin İngilizce seviyelerinin yeterli düzeyde olmadığı anlaşılmaktadır. Bu yüzden müşavirlik, din görevlilerinin belirli bir süre İngilizce kurs almalarını teşvik etmekte ve desteklemektedir. Ancak birçok görevli için her zaman ciddi kurs imkânı söz konusu olamamakta, mevcut kurslar da basit düzeyde kurslar olmaktadır. Daha ciddi kurs imkânı bulan ve görev yerlerinde Türk göçmenler dışında Müslüman cemaati olan camilerdeki din görevlilerinin birkaç yıl sonra İngilizcelerini belirli bir seviyeye getirdikleri ancak sürekli Türk göçmenlerle ilişki içinde olan din görevlileri için bu gelişmenin daha sınırlı olduğu görülmektedir. Almanya'daki din görevlileri üzerine yapılan bir araştırmada da din görevlilerinin yarısı, yabancı dillerini geliştirmek için yeterli imkân bulamadıklarını ifade etmiştir. ${ }^{56}$

ABD de görev yapan imamların dil problemi, başka Müslüman toplulukların camilerinde görev yapan imamlarla ilgili de dile getirilmiş, bu kişilerin hem cami hizmetlerinde hem de resmi işlerde zorluk çekmemeleri için yeterli düzeyde Ingilizce bilgisine sahip olmaları gerektiği ifade edilmiştir. ${ }^{77}$ Dolayısıyla ABD'ye gönderilecek din görevlileri için TOEFL gibi dinleme ve konuşma becerisini ölçen sınavlardan belirli bir puan alma şartı koyulabilir. Ayrıca bu kişilerin görev yerlerine gönderilmeden önce kısa süreliğine de olsa Diyanet Center of America'da nitelikli bir kursa alınmaları ve külliye içerisindeki yoğunlukta pratik yapma imkânı bulmaları hem İngilizce sevilerini yükseltmelerine hem de ABD'de yürütecekleri din hizmetlerine yönelik ön bilgiler edinmelerine yardımcı olacağı söylenebilir.

\subsection{Din Görevlilerinin Özlük Haklarına ve Gündelik Hayatlarına Dair Problemler}

ABD'ye beş yıllığına görevlendirilen din görevlileri özellikle görevlerinin ilk aylarında bazı zorluklarla karşılaştıklarını ifade etmiştir.

56 Latifoğlu, "Yurt Dışında Görev Yapan Din Görevlilerinin Problemleri: Almanya Örneği", 12.

57 Abuelezz, Muhammed. A Survey of American Imams: Duties, Qualifications and Challenges: a Quantitative and Religious Analysis, 146-147. 
“Ehliyet alma şartları eyaletten eyalete değişiyor. Bazı eyaletlerde daha kolay olduğunu söylüyorlar. Ama genel olarak çok kolay değil. Bir diğer problem de vizeler. Vizeler dernek üzerinden, iki-iki buçuk yıl olarak alınıyor ve zaman zaman problem yaşanabiliyor" (G1).

"Din görevlilerinin özlük haklarına ve buradaki hayat şartlarına yönelik de sıkıntıları var. Ehliyet almak, araç ve sağlık sigortası yaptırmak çok kolay değil" (G2).

"Genel olarak din görevlilerinin bir vize problemi var" (G3).

"Araç ve ehliyet burada en önemli şey. İlk başta haliyle bir zorluk oluyor ama şu anda arkadaşların çoğunun ABD ehliyeti var" (G4).

“Bir din görevlisinin ABD'de kesinlikle arabasının olması gerekiyor. Arabasız herhangi bir yere gitmek mümkün değil. Gelir gelmez böyle bir sorunla karşılaşmak görevli açısından sorun oluşturabiliyor. En azından derneklerin bu konuya bir çözüm getirmesi gerekir. Burada kiliselerin en az bir arabası var. Camilerimizin de bazı işlerde kullanmak üzere bir arabası olabilir. Din görevlisi, ortamı tanıyıp bir araba alana kadar o arabayı kullanabilir" (G7).

"Hiç bilmediğiniz bir ortam. Öncelikli olarak ehliyet ve araç almanız gerekiyor. Ehliyet almanın şartları eyaletten eyalete değişiyor. Okul çağında çocuklarınız varsa bu da ayrı bir sıkıntı" (G11).

"Vize, ehliyet gibi konularda sıkıntı oluyor. Özellikle vize meselesi daha da sıkıntılı" (G13).

Din görevlilerinin ABD'de başta vize alma ve yenileme olmak üzere, araç ve ehliyet alımı, araç sigortası gibi konularda zorluklar yaşadıkları anlaşılmaktadır. Bütün gündelik hayatın özel araçla sürdürülebildiği ABD'de en temel ihtiyaçlardan biri araç ve ehliyet alımıdır. Araç satın almanın ucuz ve kolay olması yanında ehliyet alımı ve araç sigortasının bazı zorluklarının olduğu; ehliyet ve sigorta konusunun eyaletten eyalete farklılık gösterdiği ve bunların özellikle din görevlilerinin ilk zamanlarında zorluk yaşamalarına neden olduğu anlaşılmaktadır. Abuelezz'in araştırmasında da ABD'de görev yapan imamların, sağlık sigortası, düşük gelir ve sözleşmelerde emeklilik maaşlarının olmaması gibi finansal problemler yaşadığı tespit edilmiştir. ${ }^{58}$

Görüşmelerde dile getirilen konulardan bir diğeri de toplam beş yıllık sürenin bitiminde görev süresinin uzatılıp uzatılmamasına yönelik değerlendirmedir.

"Eğer hoca ve cemaat uzatmak istiyorsa din görevlilerinin süresi uzatılabilir. Burada bu işin faydalı olup olmayacağına bakmak lazım" (G3).

58 Abuelezz, A Survey of American Imams: Duties, Qualifications and Challenges: a Quantitative and Religious Analysis, 145. 
"Bir din görevlisinin bulunduğu bölgeye alışması ve orayı tanıması birkaç senesini alabiliyor. En verimli olacağı bir dönemde görev süresi bitiyor. Beş senenin sonunda vize sorunu olmayan bir görevli kalmak isterse derneklerin maaş ödemesi isteniyor. Bu durum bazı problemlere yol açabiliyor. Derneğin maaş ödemesi karşılığında görev yapmak görevliyi minnet altında bırakıyor" (G7).

"Birçok kişi daha verimli olabileceği bir zamanda görev süresi biterekTürkiye'ye geri dönüyor. Görevlilerinin beş yıldan sonra ABD'de görev yapmalarına imkân verecek uygulama çok yönlü olarak ele alınmalı ve tartışılmalıdır. Sürenin uzatılması her görevli için söz konusu olmayabilir veya aynı yerde olmayabilir" (G9).

"Başarılı olan, müşavirliğin ve cemaatin istediği din görevlisinin görev süreleri uzatılabilir" (G13).

"Görev sürelerinin uzatılıp uzatılmaması konusunda çok şey söylenebilir. Çok yönlü ele alınması gereken bir konu. Bu konuda çok net bir fikrim yok" (G14).

Genel olarak din görevlilerinin toplam beş yıllık görev sürelerinin bazı durumlarda ve şartlar altında uzatılabileceği görüşünde oldukları anlaşılmaktadır. ABD gibi dil bilgisinin ve ülke tecrübesinin çok önemli olduğu ülkelerde ciddi birikim ve tecrübe kazanmış görevlilerden daha fazla süre istifade edilebileceği söylenebilir. Onay'ın Danimarka'daki din hizmetlerine yönelik çalışmasında da, din görevlilerinin ancak bir-iki yılın sonunda ülkeye uyum sağlayabildiği, ancak din görevlisinin yurtdışı görev süresinin dolup beşinci yılın sonunda dönecek olmasının hizmetlerin derinlik ve devamlılık kazanmasına imkân vermediği; bunun da uzun vadeli din hizmetlerinin planlanıp uygulanmasının önünde duran ciddi engellerden birisi olduğu vurgulanmıştır. ${ }^{59}$ Ancak bu sürenin uzatılıp uzatılamayacağı, uzatılması durumunda ne tür problemlerin ortaya çıkabileceği, uzatılmasının ABD'deki Dỉ'in hizmetlerine nasıl bir katkısının olacağı, uzatılması söz konusu olduğunda hangi şartlarda uzatılabileceği gibi konuların etraflıca tartışılması gerekmektedir. Uzun yıllardır yurt dışı deneyimine sahip Dỉ'in, konuyu çeşitli paydaşlarla da görüşerek değerlendirebilecek durumda olduğu söylenebilir.

\section{SONUÇ}

Türk göçmenlerin yeni nesillerinde yaşanmaya başlayan dini ve kültürel kimliğe ait problemler olduğu ve genel olarak "erime potası" kavramı içinde değerlendirilebilecek, ABD doğumlu Türk göçmenlerin "farkında olmadan" Amerikan kültürü içerisinde kaybolma ihtimaline yönelik endişelerin olduğu söylenebilir. Bu bakımdan başta genç nesiller olmak üzere Türk göçmenlerin dini sosyalleşmelerinin merkezinde yer alan camilerin çoğaltılması; bunun yanında

59 Onay, “Batı'da Sosyal Çevre ve Din, Danimarka'da Müslüman Türk Toplumu”, 157. 
içinde üretilen hizmetin daha nitelikli hale getirilmesi gerektiği anlaşılmaktadır. DiB'in ABD'deki camilerde yürüttüğü mevcut hizmetlerin Türk göçmenlerin dini ve kültürel kimliklerine önemli katkıları yanında birtakım eksiklikler taşıdığı da görülmektedir.

DiB'in camilerdeki hizmetlerde mevcut alışkanlıkları göz önünde bulundurarak hareket ettiği ve dolayısıyla bir geleneğinin, kendine has bir tavır ve tarzının olmadığı şeklinde bir eleştiri söz konusu olmuştur. Bu konunun DiB'in ve dolayısıyla müşavirliklerin yurt dışı hizmetlerinde "inisiyatif" almaktan çekinen genel tutumuyla doğrudan ilişkili olduğu ve uzun yıllardır yurt dışı hizmetlerine yönelik önemli bir deneyime sahip olduğu görülen DiB'in, her cami ve bölgenin kendine has özelliklerini dikkate almanın yanında, yürüttüğü din hizmetlerine yönelik belirli bir standardı; tarz, tavır ve üslubu geliştirebileceği söylenebilir.

Camilerde çocuklara yönelik yürütülen dini eğitim faaliyetleriyle ilgili olarak, bazı camilerdeki mevcut mekânların ve dersliklerin çocukların eğitimi için yeterli ve uygun olmadığı; velilerin çocukların dini eğitimiyle yeterince ilgilenmediği; özellikle çocukların yoğun katılımının olduğu dönemlerde mevcut din görevlisinin/görevlilerinin yeterli olmadığı; camilerde yürütülen eğitimlerde ABD'deki çocukların yetişme ve öğrenme/öğrencilik pratiklerine uygun yazılı, sesli ve görsel yeterli İngilizce dini kaynağın olmadığı; çocukların dini eğitimi ve sosyalleşmeleri için yatılı kampüs ve kamp alanlarına ihtiyaç duyulduğu anlaşılmaktadır.

Camilerde verilen dini eğitim yanında, Türkçe ve tarih derslerinin de verilmesi ve mümkünse $D i B$ 'in öncülüğünde Türk okullarının açılmasının talep edildiği görülmektedir. DíB'in 2015 yılında ABD'deki gençlere yönelik Bursa'da yaptığı yaz kampı benzeri organizasyonların, daha önceki eksiklikler giderilerek daha kapsamlı, titizveilgiçekici bir programla heryıl farklışehirlerdeyapılması, gençlerin dinlerine ve ülkelerine ait bilgi ve duygularının güçlenmesi açısından önemli olduğu söylenebilir. Çocukların ve/ya gençlerin eğitimine yönelik uygulamalarda, daha önce uygulamaya konulmuş ancak istenilen verimin alınamamış olduğu programların niçin başarılı olamadığına bakılabilir. Örneğin, yurtdışında ikamet eden gençlerin Türkiye'ye gelerek üniversite eğitimi almalarını ve geri dönerek yurtdışında yaşayan göçmenlere hizmet etmelerini planlayan Uluslararası Ilahiyat Programı́na devam eden öğrenci sayısının azlığı bize göçmenlerin Türkiye'de yapılan herhangi bir projeye katıldıklarında yaşayabilecekleri uyum sorunlarına ilişkin ipuçları vermektedir. Bu noktada, Bursa'daki yaz kampı gibi daha kısa süreli ve daha erken yaştaki gençleri kapsayan projelerin yaygınlaştırılarak daha uzun süreli ve daha ileri yaşlardaki gençlere yönelik hizmetlerin uzun vadede planlanmasının daha verimli sonuçlar verebileceği söylenebilir.

ABD'de yürütülen din hizmetlerinde kadın din görevlisi faktörünün çok önemli olduğu ve mevcut sayının arttırılması gerektiği; uzun yıllardır ihmal 
edilen bir konu olarak yurt dışı hizmetlerinde kadın din görevlisi istihdam edilmemesinin, çocukların sorumluluklarının büyük oranda üzerlerinde olduğu kadın göçmenlerin ve dolayısıyla yeni nesillerin dini ve kültürel hayatında olumsuzluklara yol açtığı söylenebilir. Kadın din görevlisi eksikliğinin nedenlerine ilişkin kapsamlı bir çalışma yapılarak, mümkün olan en kısa zamanda bu nedenlerin yarattığı olumsuzlukların giderilmesine ilişkin projeler geliştirmek yararlı olacaktır. Çocukların eğitimi ve günlük pratiklerinde genellikle annelerin ön planda olduğu düşünüldüğünde, kadın din görevlilerinin hem annenin hem de çocukların dini eğitim ve sosyalleşmesindeki etkileri daha iyi anlaşılacaktır.

Din görevlilerinin İngilizce bilmelerinin yürütülen hizmetlerde etkili olduğu; özellikle Türkçe bilgilerinin çok sınırlı olduğu yeni nesille ilişkilerde daha da önemli hale geldiği anlaşılmaktadır. Din görevlilerinin herhangi bir yabancı dil şartı aranmaksızın yurtdışı görevine gönderilmesi verilen hizmetin niteliğine dair çekinceler doğurmaktadır. Dil problemi, yalnızca hizmet alan vatandaşlarla yaşanılan iletişim zorluklarını değil, din görevlilerinin gittikleri ülkede gündelik hayatlarını yürütürken yaşadıkları zorlulukları da beraberinde getirmektedir. Ayrıca daha önce hiç yaşanılmamış olan bir yere uyum sağlama süresini göz önünde bulundurarak, din görevlilerinin yurtdışındaki görev sürelerine ilişkin uygulamaların da yeniden gözden geçirilmesini önermek mümkündür.

\section{KAYNAKÇA}

Abadan Unat, Nermin. Bitmeyen Göç: Konuk Iş̧̧̧ilikten Ulus-Ötesi Yurttaşlığa. İstanbul: İstanbul Bilgi Üniversitesi Yayınları, 2006.

Abuelezz, Muhammed. A Survey of American Imams: Duties, Qualifications and Challenges: a Quantitative and Religious Analysis, (Doctoral dissertation), University of Georgia, 2011.

Ahmed, Sameera - Patel, Sadiq - Hashem, Hanan. "State of American Muslim Youth: Research \& Recommendations". Canton, MI:Institute for Social Policy and Understanding and The Family \& Youth Institute, 2015.

Bagby, Ihsan. "The American Mosque: Activities, Administration, and Vitality of the American Mosque: Report Number 2 from the US Mosque Study 2011". Institute of Religion Study, 2012.

Bagby, Ihsan. "The American Mosque: Report Number 1 from the US Mosque Study 2011". Islamic Society of North America 1/2 (2012).

Başkurt, İrfan. "Almanya'da Yaşayan Türk Göçmenlerin Kimlik Problemi". Hasan Ali Yücel Eğitim Fakültesi Dergisi 12/2 (2009): 81-94.

Çelik, Celalettin. "Almanya'da Türkler: Sürekli Yabancılık, Kültürel Çatışma ve Din”. Milel ve Nihal Inanç, Kültür ve Mitoloji Araştırmaları Dergisi 5/3 (2008): 105-142.

Çoştu, Yakup - Ceyhan, Mehmet Akif. "DiтiB'in Din Eğitimi Faaliyetleri Üzerine Bir Değerlendirme". Hitit Üniversitesi Sosyal Bilimler Enstitüsü Dergisi 8/1 (2015): 39-51. 
Çoştu, Yakup - Turan, Süleyman. "Ingiltere'deki Türk Camileri ve Entegrasyon Sürecine Sosyo-Kültürel Katkıları". Dinbilimleri Akademik Araştırma Dergisi 9/4 (2009): 35-52.

Çoştu, Yakup. Ingiltere'de Türkler (Yapı ve Organizasyonlar). Ankara: Araştırma Yayınları, 2018.

Erşahin, İsmail. "Bir Diyanet Projesi Olarak Uluslararası Illahiyat Programı". Diyanet IImi Dergi 51/2 (2015): 125-146.

Gemici, Nurettin. “Uluslararası Illahiyat Projesi ve Diyanet İşleri Türk-İslam Birliği (DiTiB)’nin Almanya'daki Din Hizmetlerine Katkısı". Değerler Ĕğitimi Dergisi 13/30 (2015): 181-211.

Glazer, Nathan - Moynihan, Daniel Patrick. Beyond the Melting Pot: The Negroes, Puerto Ricans, Jews, Italians, and Irish of New York City. Cambridge, MA: mit Press, 1970.

Gordon, Milton. M. Assimilation in American life. Oxford University Press, 1964.

Güler, Müzeyyen. "Turkish immigrants in the United States: Men, Women and Ghildren". Turkish Migration to the United States: From Ottoman Times to the Present. ed. Balgamis, A. Deniz- Karpat, Kemal. H., University of Wisconsin Press, 2008, 151-171.

Güllü, İsmail. "Yeni Türk Sosyolojisi Bağlamında Almanya'daki Göçmen Türk Çocuklarının Dini Toplumsallaşması". Sosyoloji Divanı 3/6 (2015): 83-102.

Güngör, Özcan. "1.5 ve 2. Nesil Türk Gençlerinin Ailede Dini Sosyalleşmeleri: New Jersey, USA Örneği”. Ankara Üniversitesi Ilahiyat Fakültesi Dergisi 53/2 (2012): 85-119.

Güngör, Özcan. "Akran Gruplarının Amerikalı Türk Gençlerinin Dini Sosyalleşmelerine Etkileri (12-15 Yaş)". Değerler Eğitimi Dergisi 12/30 (2015): 213-249.

Güngör, Özcan. "Amerika'da Türkler ve Türklerin Dini Kurumsallaşmaları Açısından Camiler". Ekev Akademi Dergisi 15/47 (2011): 85-101.

Güngör, Özcan. "The Process of Religious Institutionalization (Concept of Mosque) of Turkish in the US". International Journal of Business and Social Science 2/8 (2011): 211222.

Güngör, Özcan. Iki Dünya Bir Aile. Ankara: Akçağ Yayınları, 2016.

Jimenez, Tomas. The other Side of Assimilation: How Immigrants are Changing American Life. University of California Press, 2017.

Kara, İsmail. Cumhuriyet Türkiye'sinde Bir Mesele Olarak Islam. İstanbul: Dergâh Yayınları, 2008.

Karpat, Kemal. "Câliye", Türkiye Diyanet Vakfı İlâm Ansiklopedisi. Ankara: TDV Yayınları, 1993, 7/34-38.

Karpat, Kemal. "The Turks Finally Establish a Community in the United States". Turkish Migration to the United States: From Ottoman Times to the Present. ed. Balgamis, A. Deniz- Karpat, Kemal. H., University of Wisconsin Press, 2008, 173-193.

Kaya, IIlhan. "Amerikalı Türkler". Coğrafi Bilimler Dergisi 4/2 (2006): 1-13.

Kaya, IIlhan. Müslüman Amerikalılar: Göç, Kimlik ve Entegrasyon. Ankara: Dipnot Yayınları, 2007.

Kaya, İlhan. Shifting Turkish American Identity Formationsin the United States. Doctoral dissertation, Florida State University, 2003.

Korkmaz, Arif. Göç ve Din. Konya: Çizgi Kitabevi, 2017. 
Kurt, Halil - Açıkgöz, Mehmet Ali. "ABD'de Yaşayan Ahıska Türkleri". MUTAD 4/1 (2017): 107-127.

Latifoğlu, Fatma. "Yurt Dışında Görev Yapan Din Görevlilerinin Problemleri: Almanya Örneği". PESA Uluslararası Sosyal Araştırmalar Dergisi 1/2 (2016), 1-15.

Lean, Nathan. İslamofobi Endüstrisi. Trc. İbrahim Yılmaz. Ankara: Diyanet İşleri Başkanlığı Yayınları, 2015.

Lipka, Michael. "Muslims and Islam: Key findings in the US and around the world". Pew Research Center 9 (2017).

Macionis, John J. Sociology. New Jersey: Upper Saddle River, Pearson Education, 2012.

Mevzuat Bilgi Sistemi (MBS). Diyanet İşleri Başkanlığı Kuruluş Ve Görevleri Hakkında Kanun, 1965. Erişim: 28.07.2018. http://www.mevzuat.gov.tr/MevzuatMetin/1.5.633.pdf

Onay, Ahmet. "Batı'da Sosyal Çevre ve Din, Danimarka'da Müslüman Türk Toplumu". Değerler Eğitimi Dergisi 15/33 (2017): 139-176.

Orosco, José-Antonio. Toppling the Melting Pot: Immigration and Multiculturalism in American Pragmatism. Indiana University Press, 2016.

Read, Jen'nan Ghazal. "Gender, Religious Identity, and Civic Engagement among Arab Muslims in the United States". Sociology of Religion 76/1 (2014): 30-48.

Rubin, Rachel Lee - Melnick, Jeffrey. "Popular Culture and Immigration". Migrant Marginality: A Transnational Perspective. ed. Kretsedemas, Philip- Capetillo-Ponce, Jorge-Jacobs, Glenn. Routledge, 2013.

Sayeed, Sarah - Al-Adawlya, Alisha - Bagby, Ihsan. "The American Mosque: Women and the American Mosque: Report Number 3 from the US Mosque Study 2011". Islamic Society of North America, 2013.

Smith, Jane I. "Islam in America". Muslims in the West after 9/11: Religion, Politics and Law. ed. Jocelyne Cesari, (Routledge, 2009), 38-52.

Tavukçuoğlu, Mustafa. Belçika'da Türk Ailesi ve Din Eğitimi. Konya: Mehir Vakfı, 2000.

Tekelioğlu, Ahmet Selim. Yerleşme ve Yerelleşme Arasında Amerika'da İslam ve Müslümanlar: Tarihi Perspektif ve Güncel Dinamikler. Vaşington: Diyanet Center of America, 2017.

Worldometers. "Countries in the World by Population". 2017.

Yavuzer, Hasan. "Amerika'daki Türkler ve Kurmuş Oldukları Türk Dernekleri". Zeitschrift für die Welt der Türken/Journal of World of Turks 1/1 (2009): 171-198.

Yavuzer, Hasan. "Amerika'daki Türkler ve Kendilerine Götürülen Din Hizmetleri". Türk Dünyası Araştırmaları 189 (2010): 159-183.

Yiğittürk Ekiyor, Emel. "Ulusaşırı Bağlar ve Dil: ABD'de Yaşayan Türkler Örneği”. Avrasya Sosyal ve Ekonomi Araştırmaları Dergisi (ASEAD) 5/2 (2018): 37-51.

Yücel, İrfan. “Diyanet İşleri Başkanlığı”. Türkiye Diyanet Vakfı İslâm Ansiklopedisi. 9: 455-460. Ankara: TDV Yayınları, 1994. 
